\title{
Mangrove derived Streptomyces sp. MUM265 as a potential source of antioxidant and anticolon-cancer agents
}

\author{
Loh Teng-Hern Tan ${ }^{1,2,3}$, Kok-Gan Chan ${ }^{4,5^{*}}$, Priyia Pusparajah ${ }^{6}$, Wai-Fong Yin ${ }^{5}$, Tahir Mehmood Khan 1,2,6,
} Learn-Han Lee $3,7,8^{*}$ and Bey-Hing Goh ${ }^{2,7,8^{*}}$ (D)

\begin{abstract}
Background: Colon cancer is the third most commonly diagnosed cancer worldwide, with a commensurately high mortality rate. The search for novel antioxidants and specific anticancer agents which may inhibit, delay or reverse the development of colon cancer is thus an area of great interest; Streptomyces bacteria have been demonstrated to be a source of such agents.

Results: The extract from Streptomyces sp. MUM265 - a strain which was isolated and identified from Kuala Selangor mangrove forest, Selangor, Malaysia - was analyzed and found to exhibit antioxidant properties as demonstrated via metal-chelating ability as well as superoxide anion, DPPH and ABTS radical scavenging activities. This study also showed that MUM265 extract demonstrated cytotoxicity against colon cancer cells as evidenced by the reduced cell viability of Caco-2 cell line. Treatment with MUM265 extract induced depolarization of mitochondrial membrane potential and accumulation of subG ${ }_{1}$ cells in cell cycle analysis, suggesting that MUM265 exerted apoptosis-inducing effects on Caco-2 cells.

Conclusion: These findings indicate that mangrove derived Streptomyces sp. MUM265 represents a valuable bioresource of bioactive compounds for the future development of chemopreventive agents, with particular promise suggested for treatment of colon cancer.
\end{abstract}

Keywords: Streptomyces, Mangroves, Antioxidant, Cytotoxic, Colon cancer

\section{Background}

Colon cancer is a global concern, ranking 3rd out of 27 common cancers across 184 countries [1]; while it once viewed as a disease affecting developed countries, recent data suggests that the incidence of colon cancer is increasing among the Asia-Pacific population. A variety of possible reasons have been postulated to explain this observation including increasing life expectancy, adoption

\footnotetext{
*Correspondence: kokgan@um.edu.my; lee.learn.han@monash.edu; leelearnhan@yahoo.com; goh.bey.hing@monash.edu

${ }^{4}$ International Genome Centre, Jiangsu University, Zhenjiang, China ${ }^{3}$ Novel Bacteria and Drug Discovery (NBDD) Research Group, Microbiome and Bioresource Research Strength, Jeffrey Cheah School of Medicine and Health Sciences, Monash University Malaysia, 47500 Bandar Sunway, Selangor Darul Ehsan, Malaysia

${ }^{2}$ Biofunctional Molecule Exploratory (BMEX) Research Group, School of Pharmacy, Monash University Malaysia, 47500 Bandar Sunway, Selangor Darul Ehsan, Malaysia

Full list of author information is available at the end of the article
}

of Western lifestyle [2] as well as lifestyle changes occurring in parallel with economic development including diet-related factors [3], physical inactivity, obesity, smoking, and alcohol consumption [4,5]. Worldwide mortality attributable to colorectal cancer is approximately half that of the incidence; colorectal cancer is the fourth most common cause cancer related deaths worldwide [4]. Given these statistics, new drugs that have the potential to delay or prevent malignant growths in the colon therefore potentially reducing the incidence and therefore mortality rates would be of tremendous value.

The new molecules we seek may come from an unlikely source: bacteria from mangrove swamps, which are the woody plant areas in the intertidal coasts in tropical and subtropical coastal regions. These areas are home to a diverse array of unique microorganisms; and represents an excellent target in the hunt for novel

(c) The Author(s). 2019 Open Access This article is distributed under the terms of the Creative Commons Attribution 4.0 International License (http://creativecommons.org/licenses/by/4.0/), which permits unrestricted use, distribution, and 
metabolites as the mangrove ecosystem places constant environmental stressors on its inhabitants with its constant changes of salinity and tidal gradients [6, 7] which then drives metabolic pathway adaptations for survival among the mangrove-associated microorganisms. These metabolic adaptations are likely to result in the synthesis of medically valuable, bioactive metabolites [8-10]. Exploration of the mangrove is all the more exciting as recently many new species have been discovered suggesting the huge untapped potential of this environment $[11,12]$. Work on this has so far resulted in the discovery of several novel Streptomyces species from mangrove environments on a global scale including S. shenzhenensis [13], S. pluripotens [14], S. ferrugineus [15], S. mangrovisoli [16], S. gilvigriseus [17], S. malaysiense [18], S. humi [19], S. antioxidans [20] and S. colonosanans [21].

The discovery of novel Streptomyces species is particularly exciting as Streptomyces are a prolific source of various natural products with diverse biological activities [22, 23]. Notably, Streptomyces is a producer of many clinically important drugs, including the anticancer agents doxorubicin [24] and bleomycin [25], as well as the antifungal agent nystatin [26]. It stands to reason that the Streptomyces species derived from previously unexplored environments such as the mangrove ecosystem are highly likely to be producers of valuable secondary metabolites with interesting bioactivities $[9,27-$ 30]. Conventionally, plants have been heralded as a rich source of antioxidants which have potential to treat many diseases including cancer [31-33] and much work in drug discovery has focused on them; but recently, work with microorganisms has demonstrated that they may also represent a rich source of natural antioxidants. Furthermore, recent research has revealed that mangrove Streptomyces produce metabolites with antioxidative activity [16, 29, 34]. Previous studies have reported that Streptomyces sp. produce a number of bioactive compounds with anticancer and antitumor properties, particularly against colon cancer - piperazimycins [35], pladienolides [36], and calcimycin [37] are some of the bioactive compounds isolated from Streptomyces sp. that exhibit cytotoxicity toward human colon cancer cells. Research findings have also suggested that Streptomyces is potentially a good source of chemopreventive agents [18, 38, 39]. The chemopreventive properties of phenazine compounds isolated from a marine-derived Streptomyces sp. have been extensively studied and were demonstrated to have chemopreventive potential, as evidenced by inhibition of quinone reductase 2 (phase II enzymes), induction of quinone reductase 1 (phase I enzymes), inhibition of cyclooxygenase and induction of apoptosis through subG1 phase cell cycle arrest [38, 39].

The aim of this study is to explore the biological activity of Streptomyces sp. MUM265, which our team isolated from soil samples from the Kuala Selangor mangrove forest on the west coast of Peninsula Malaysia. This work represents part of our bioprospecting effort to explore the potential biological activities of new strains of Streptomyces, focusing on their antioxidant and cytotoxic properties. The results we obtained indicate that MUM265 extract possesses significant antioxidant properties and is cytotoxic against colon cancer cells. GC-MS chemical profiling identified several bioactive chemical compounds present in the extract of MUM265. A good correlation was observed between the chemical constituents identified from MUM265 extract and its antioxidant and cytotoxic properties. Thus, the outcomes derived from this research continue to build on the foundation supporting the continued bioprospecting of mangrove derived Streptomyces as sources of potential chemopreventive agents in greater depth, with a particular focus on the development of chemopreventive drugs for colon cancer.

\section{Results}

\section{Strain identification using 16S rRNA-based phylogenetic analysis}

The sequencing result revealed a $1340 \mathrm{bp}$ 16S rRNA gene sequence of strain MUM265 which has been submitted and deposited in GenBank with accession number (KY656444). Figure 1 shows a 16S rRNA gene phylogenetic tree of strain MUM265 based on neighbor-joining method which demonstrated a single clade formed between strain MUM265 and another two type strains, including the Streptomyces misionensis NBRC $13063^{\mathrm{T}}$ and Streptomyces phaeoluteichromatogenes NRRL $5799^{\mathrm{T}}$. This clade is also supported by the high bootstrap value of $91 \%$, showing a high confidence level of the association. Strain MUM265 was found to be closely related with Streptomyces misionensis $\mathrm{NBRC}_{13603}{ }^{\mathrm{T}}$ (99.8\%) and Streptomyces phaeoluteichromatogenes NRRL $5799^{\mathrm{T}}$ (99.8\%) with high $16 \mathrm{~S}$ rRNA gene sequence similarity.

\section{Phenotypic characterization of strain MUM265}

Streptomyces sp. MUM265 is Gram-positive and aerobic. On ISP2 agar, it forms brilliant yellow aerial and light-yellow substrate mycelium. The color of Streptomyces sp. MUM265 colony varies on different media. The strain grows well on all the agar tested after 2 weeks at $28^{\circ} \mathrm{C}$, except on ISP 4 agar (no growth). When subjected to scanning electron microscopy, strain MUM265 was shown to produce spiral spore chains (Fig. 2). These morphological characteristics also strongly indicated that strain MUM265 belonged to the genus Streptomyces [40]. Strain MUM265 was also shown to be negative for haemolytic activity as no clear zone was observed around the colonies formed on the blood agar. The biochemical and growth characteristics of strain MUM265 


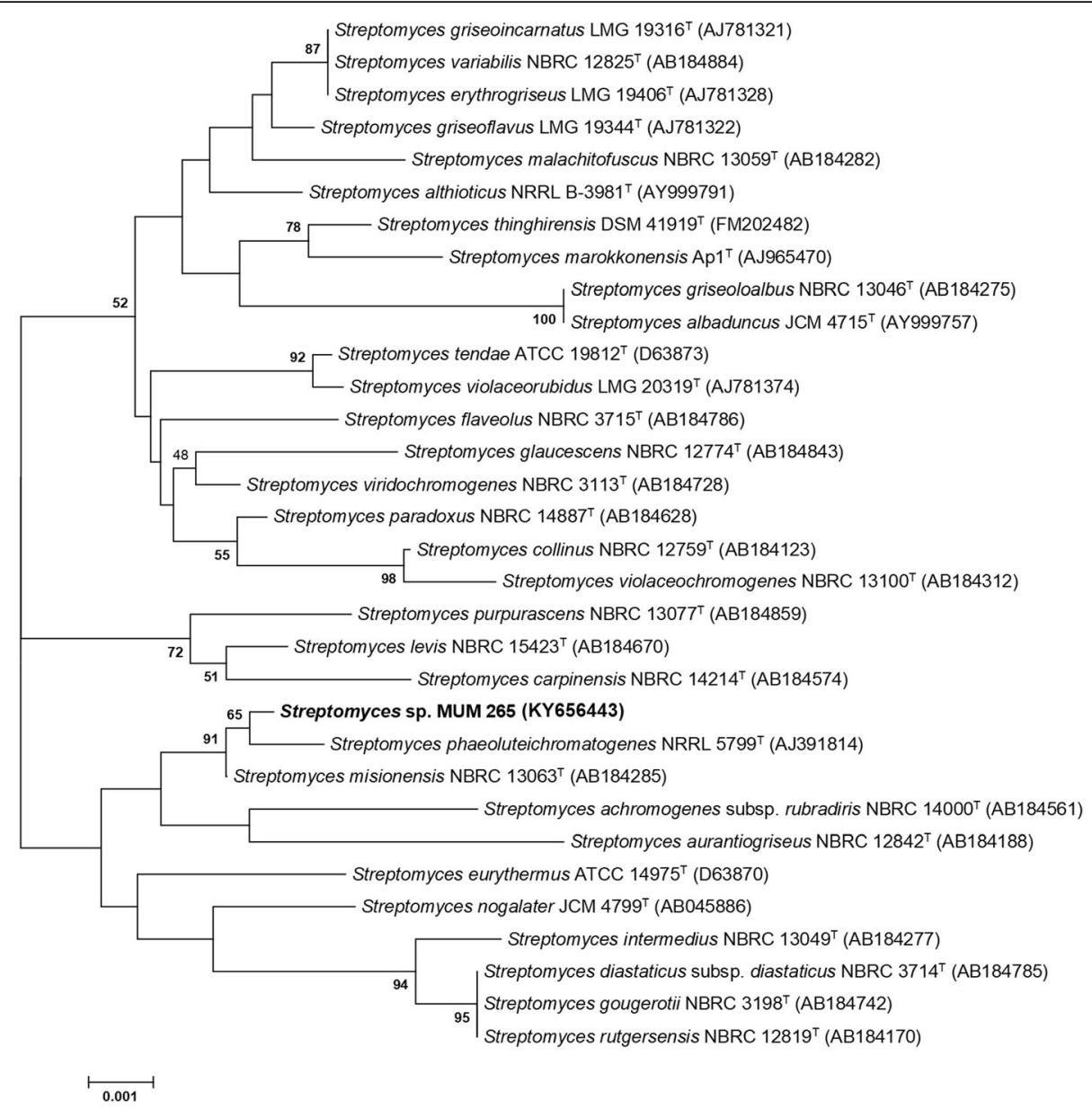

Fig. 1 Neighbour-joining phylogenetic tree based on 16S rRNA sequences of strain MUM265 and other related taxa. Bootstrap values (> 50\%) based on 1000 re-sampled datasets are shown at branch nodes. Bar, 0.001 substitutions per site

cultured under different growth conditions are tabulated in Table 1. An interesting additional finding of ours was that strain MUM265 hydrolyzes starch and cellulose, indicating that strain MUM265 possesses the potential to be an industrially important strain that produces enzymes which are valuable for the pharmaceutical and food industries [41].

Physiological factors and carbon sources are important determinants influencing secondary metabolite production in Streptomyces species [42, 43]. Small manipulations of nutritional or environmental factors during cultivation may significantly impact the quantity of a particular compound that is produced or even the general metabolic profile of the Streptomyces species. The physiological tests conducted revealed that strain MUM265 exhibits moderate salt and temperature tolerance (up to $6 \% w / v$ and $40{ }^{\circ} \mathrm{C}$ respectively). This is in agreement with other studies on mangrove derived Streptomyces strains that also demonstrated tolerance to moderate to high $\mathrm{NaCl}$ concentrations ranging from 6 to $10 \%(\mathrm{w} / \mathrm{v})[44,45]$.
The biosynthesis of secondary metabolites in Streptomyces sp. is significantly dependent on the availability of carbon and nitrogen sources; therefore varying the composition of substrates provided can result in the production of a varied quantity of compounds and also the production of distinct groups of molecules $[42,46]$. Thus, the carbon and nitrogen source utilization of strain MUM265 was assessed by employing the Biolog GEN III MicroPlate system to obtain an overview of its metabolic profile. Strain MUM265 was shown to have the capability to use a great variety of different substrates. The results are interpreted and summarized in Table 2 . The system also showed that growth of strain MUM265 is not inhibited by azetreonam, guanidine $\mathrm{HCl}$, rifamycin $\mathrm{RV}$, tetrazolium blue, tetrazolium violet, potassium tellurite, sodium butyrate, sodium bromate and 1\% sodium lactate. Moreover, the antibiotic susceptibility test showed that strain MUM265 is resistant to penicillin G, ampicillin and nalidixic acid but could not be inhibited by vancomycin, erythromycin, chloramphenicol, 


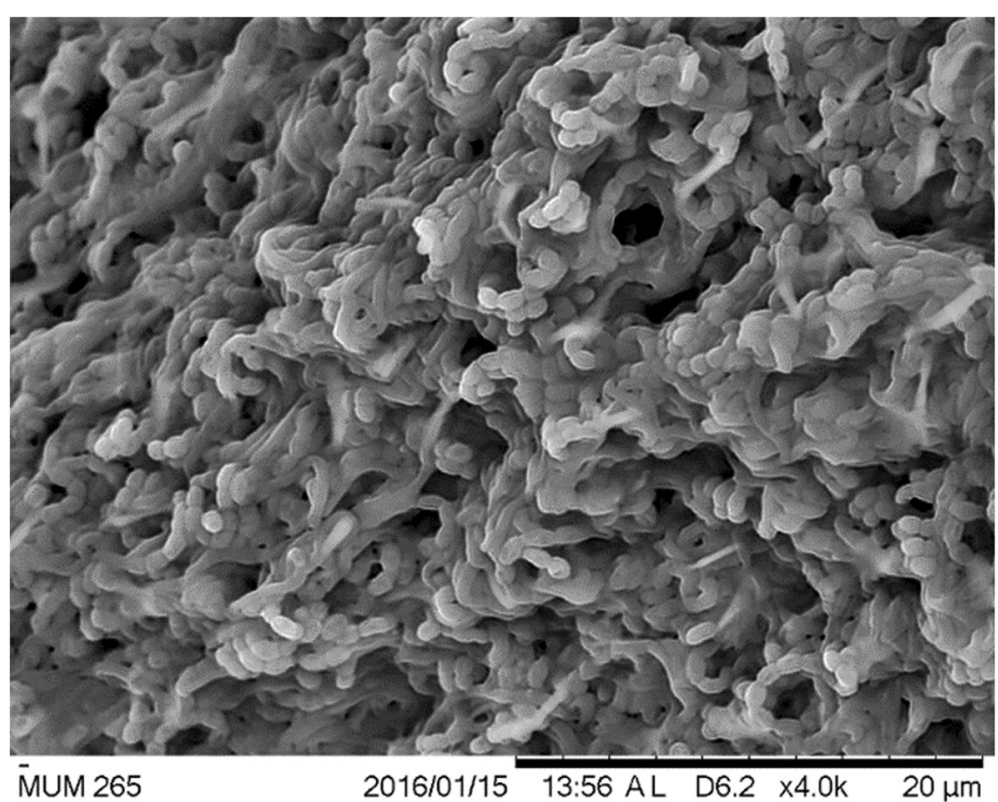

Fig. 2 The scanning electron micrographs of Streptomyces sp. MUM265. It appears as filaments and branch to form a network of filaments called mycelium. Spiral shape spore chains are also clearly visible in SEM micrographs

ampicillin-sulbactam, cefotaxime, gentamicin and tetracycline (see Additional file 1).

\section{Antioxidant activities of MUM265 extract}

To evaluate the antioxidant potential of Streptomyces sp. MUM265 extract, four different antioxidant assays were conducted. The results of its antioxidant activity as measured by the different assays are presented in Table 3 .

Our results showed that Streptomyces sp. MUM265 extract exhibited significant DPPH scavenging activity over a range of extract concentrations from 0.5 to

Table 1 The phenotypic and physiological characteristics of Streptomyces sp. MUM265

\begin{tabular}{ll}
\hline Characteristics & Strain MUM265 \\
\hline Tolerance to $\mathrm{NaCl}$ & Up to $6 \%(\mathrm{~W} / \mathrm{v})$ \\
& (optimum at $2 \%(\mathrm{~W} / \mathrm{V}))$ \\
Temperature optimum & Up to $40^{\circ} \mathrm{C}\left(36^{\circ} \mathrm{C}\right)$ \\
$\mathrm{pH}$ optimum & $6-7$ \\
Melanin production & - \\
Haemolytic activity & $\mathrm{\gamma}$ (gamma)/negative \\
Hydrolysis of: & \\
Carbomethylcellulose & + \\
Casein & - \\
Catalase & + \\
Chitin & - \\
Starch & + \\
Tributyrin & - \\
Xylan & - \\
\hline
\end{tabular}

$4 \mathrm{mg} / \mathrm{mL}(p<0.05)$ with a $9.43 \pm 1.22 \%$ to $42.33 \pm 3.99 \%$ reduction of DPPH radicals. The radical scavenging activity of Streptomyces sp. MUM265 extract was also evaluated using another stable radical cation, $\mathrm{ABTS}^{\bullet+}$. This assay showed that Streptomyces sp. MUM265 extract scavenged ABTS radical with capacity measuring from $9.40 \pm 3.17 \%$ to $88.50 \pm 0.37 \%$ at extract concentrations ranging from $0.125 \mathrm{mg} / \mathrm{mL}$ to $4 \mathrm{mg} / \mathrm{mL}$. The ability of Streptomyces sp. MUM265 extract to scavenge superoxide anion radical $\left(\mathrm{O}_{2}{ }^{\bullet-}\right)$ was assessed by detecting the reduction of $\mathrm{O}_{2}{ }^{\bullet-}$ level with WST-1 for the determination of SOD-like activity [47]. The assay revealed that Streptomyces sp. MUM265 extract demonstrated significant superoxide anion scavenging activity ranging from $9.73 \pm 5.72 \%$ to $55.99 \pm 1.03 \%$ over a range of extract concentrations from $0.0625 \mathrm{mg} / \mathrm{mL}$ to $4 \mathrm{mg} / \mathrm{mL}(p<0.05)$. The metal-chelating activity of Streptomyces sp. MUM265 extract was evaluated by measuring the reduction of ferrozine- $\mathrm{Fe}^{2+}$ complex formation. This assay showed that Streptomyces sp. MUM265 extract possesses significant metal chelating activity in terms of inhibiting the formation of ferrozine- $\mathrm{Fe}^{2+}$ complex, measuring from $12.57 \pm 2.10 \%$ to $46.02 \pm 0.86 \%$ at extract concentrations tested from $0.0625 \mathrm{mg} / \mathrm{mL}$ to $4 \mathrm{mg} / \mathrm{mL}$.

Studies have shown that phenolic compounds and flavonoids -both effective antioxidants - are naturally present in microorganisms [48-50]. On this basis, we chose to perform assays to determine the total phenolic and flavonoid content of the extract. We also performed a correlation analysis to evaluate the relationship between the antioxidant capacity of MUM265 extract and its total phenolic content (TPC). TPC of 
Table 2 The utilization of carbon and nitrogen sources by Streptomyces sp. MUM265

\begin{tabular}{|c|c|c|c|}
\hline \multicolumn{2}{|c|}{$\begin{array}{l}\text { Utilizable carbon and } \\
\text { nitrogen sources }\end{array}$} & \multicolumn{2}{|c|}{$\begin{array}{l}\text { Non-utilizable carbon } \\
\text { and nitrogen sources }\end{array}$} \\
\hline Acetic acid & a-D-glucose & 3-methylglucose & $\begin{array}{l}\text { Acetoacetic } \\
\text { acid }\end{array}$ \\
\hline $\begin{array}{l}\text { a-hydroxy- } \\
\text { butyric acid }\end{array}$ & $\begin{array}{l}\text { a-keto-glutaric } \\
\text { acid }\end{array}$ & a-D-lactone & $\begin{array}{l}\beta \text {-methyl-D- } \\
\text { glucoside }\end{array}$ \\
\hline $\begin{array}{l}\text { B-hydroxy-D, } \\
\text { L-butyric acid }\end{array}$ & $\begin{array}{l}\text { Bromo-succinic } \\
\text { acid }\end{array}$ & D-aspartic acid & $\begin{array}{l}\text { D-glucose-6- } \\
\text { phosphate }\end{array}$ \\
\hline Citric acid & D-arabitol & $\begin{array}{l}\text { D-lactic acid } \\
\text { methyl ester }\end{array}$ & D-malic acid \\
\hline D-cellobiose & Dextrin & D-melibiose & D-raffinose \\
\hline D-fructose & $\begin{array}{l}\text { D-fructose-6- } \\
\text { phosphate }\end{array}$ & D-saccharic acid & D-salicin \\
\hline D-fucose & D-galactose & D-serine & D-sorbitol \\
\hline $\begin{array}{l}\text { D-galacturonic } \\
\text { acid }\end{array}$ & $\begin{array}{l}\text { D-gluconic } \\
\text { acid }\end{array}$ & D-turanose & L-rhamnose \\
\hline $\begin{array}{l}\text { D-glucuronic } \\
\text { acid }\end{array}$ & D-maltose & Mucic acid & $\begin{array}{l}\mathrm{N} \text {-acetyl-D- } \\
\text { galactosamine }\end{array}$ \\
\hline D-mannitol & D-mannose & $\begin{array}{l}\mathrm{N} \text {-acetyl- } \\
\text { neuraminic acid }\end{array}$ & $\begin{array}{l}\mathrm{N} \text {-acetyl- } \beta \text {-D- } \\
\text { mannosamine }\end{array}$ \\
\hline D-trehalose & Formic acid & $\begin{array}{l}\rho \text {-hydroxy- } \\
\text { phenylacetic acid }\end{array}$ & Quinic acid \\
\hline $\begin{array}{l}\text { Y-amino- } \\
\text { butyric acid }\end{array}$ & Gelatin & Stachyose & Sucrose \\
\hline Gentiobiose & Glucuronamide & & \\
\hline Glycerol & Glycyl-L-proline & & \\
\hline Inosine & L-alanine & & \\
\hline L-arginine & L-aspartic acid & & \\
\hline L-fucose & $\begin{array}{l}\text { L-galactonic acid } \\
\text { lactone }\end{array}$ & & \\
\hline $\begin{array}{l}\text { L-glutamic } \\
\text { acid }\end{array}$ & L-histidine & & \\
\hline $\begin{array}{l}\text { L-lactic } \\
\text { acid }\end{array}$ & L-malic acid & & \\
\hline $\begin{array}{l}\text { L-pyroglutamic } \\
\text { acid }\end{array}$ & L-serine & & \\
\hline $\begin{array}{l}\text { Methyl } \\
\text { pyruvate }\end{array}$ & myo-inositol & & \\
\hline $\begin{array}{l}\text { N-acetyl-D- } \\
\text { glucosamine }\end{array}$ & Pectin & & \\
\hline Propionic acid & Tween 40 & & \\
\hline
\end{tabular}

Streptomyces sp. MUM265 extract was measured using Folin-Ciocalteu's reagent and the result was suggestive of the presence of phenolic compounds as TPC increased with increasing extract concentration. Meanwhile, a negative result was shown by the flavonoid content assay, suggesting either that this assay was not sensitive enough to detect flavonoids or that the flavonoid concentration in the Streptomyces sp. MUM265 extract was too low to be detected. Table 4 shows the Pearson's correlation coefficients between the variables.
The strongest positive correlation was observed between the TPC and SOD-like activity of Streptomyces sp. MUM265 extract $(r=0.991, p<0.05)$. The strong correlation between the four assays measuring antioxidant capacity and the total phenolic content indicates that phenolic compounds are likely to be a major contributor to the antioxidant properties of Streptomyces sp. MUM265 extract. Phenolic compounds are widely recognized as potent chemopreventive agents, with their mechanism of action believed to hinge on their antioxidant action and modulation of intracellular signaling pathways associated with the initiation and promotion of carcinogenesis [51].

\section{Effect of MUM265 extract on cell viability of cancer and normal cells}

The cytotoxicity of Streptomyces sp. MUM265 extract was evaluated against various colon cancer cells. Cell viability post exposure to variable concentrations of extract was assessed via an MTT assay. CCD-18Co cells were included to evaluate the toxicity of the extract against normal cells, which served as a measure of the selectivity of the extract against cancer cells vs normal cells, a key and highly desirable quality in any chemotherapeutic agent. CCD-18Co is a human fibroblast cell line isolated from normal colon tissue and has been widely used as normal control in cancer studies [52-54].

The cytotoxicity of MUM265 extract is depicted in Fig. 3, demonstrating the cell viability of each colon cell line after exposure to MUM265 extract across a range of final concentrations for $72 \mathrm{~h}$. The cytotoxicity test revealed that Streptomyces sp. MUM265 extract in concentrations ranging from 50 to $400 \mu \mathrm{g} / \mathrm{mL}$ resulted in significant reduction of the cell viability of both HT29 and Caco- 2 cells. Caco- 2 was the most sensitive toward the Streptomyces sp. MUM265 extract among the tested cell lines, as determined by the highest reduction in cell viability of Caco-2 $(p<0.05)$ of $34.57 \pm 4.99 \%$ noted at $400 \mu \mathrm{g} / \mathrm{mL}$ extract concentration. Conversely, SW480 was not sensitive toward Streptomyces sp. MUM265 extract. There was no significant reduction in cell viability of normal colon cells, CCD-18Co treated with Streptomyces sp. MUM265 extract at concentrations tested from 25 to $400 \mu \mathrm{g} / \mathrm{mL}$. This also implies that Streptomyces sp. MUM265 extract within the concentrations tested is non-toxic toward non-cancerous cells but exerts cytotoxicity against both Caco-2 and HT29 cancer cells. This result also suggests that among various colon cancer cell lines, Streptomyces sp. MUM265 extract exhibits a preferential cytotoxicity against both HT29 and Caco-2 $(p<0.05)$. However, $\mathrm{ED}_{50}$ (dose that is required to induce $50 \%$ reduction in cell viability) was not achieved for MUM265 extract even at the highest 
Table 3 The antioxidant activities demonstrated by Streptomyces sp. MUM265 extract and positive controls in different antioxidant assays

\begin{tabular}{|c|c|c|c|c|}
\hline \multirow{2}{*}{$\begin{array}{l}\text { Concentration } \\
\text { of extract / } \\
\text { positive } \\
\text { controls } \\
(\mu \mathrm{g} / \mathrm{mL})\end{array}$} & \multicolumn{4}{|c|}{ Antioxidant activities } \\
\hline & $\begin{array}{l}\text { DPPH radical } \\
\text { scavenging } \\
\text { activity (\%) }\end{array}$ & $\begin{array}{l}\text { ABTS radical } \\
\text { scavenging } \\
\text { activity (\%) }\end{array}$ & $\begin{array}{l}\text { Superoxide } \\
\text { dismutase-like } \\
\text { activity (\%) }\end{array}$ & $\begin{array}{l}\text { Metal- } \\
\text { chelating } \\
\text { activity (\%) }\end{array}$ \\
\hline \multicolumn{5}{|c|}{ MUM265 extract } \\
\hline 62.5 & $N D^{a}$ & $5.31 \pm 2.21$ & $9.73 \pm 5.72^{*}$ & $\begin{array}{l}12.57 \pm \\
2.10^{*}\end{array}$ \\
\hline 125 & $N D^{a}$ & $9.40 \pm 3.17^{*}$ & $16.84 \pm 4.48^{*}$ & $\begin{array}{l}18.55 \pm \\
1.13^{*}\end{array}$ \\
\hline 250 & $1.22 \pm 1.47$ & $\begin{array}{l}16.42 \pm \\
4.20^{*}\end{array}$ & $17.67 \pm 2.52^{*}$ & $\begin{array}{l}22.53 \pm \\
0.70^{*}\end{array}$ \\
\hline 500 & $9.43 \pm 1.58^{*}$ & $\begin{array}{l}24.29 \pm \\
4.01^{*}\end{array}$ & $24.20 \pm 1.98^{*}$ & $\begin{array}{l}24.32 \pm \\
3.56^{*}\end{array}$ \\
\hline 1000 & $24.70 \pm 3.12^{*}$ & $\begin{array}{l}46.56 \pm \\
4.95^{*}\end{array}$ & $28.59 \pm 1.79^{*}$ & $\begin{array}{l}28.86 \pm \\
6.27^{*}\end{array}$ \\
\hline 2000 & $33.69 \pm 3.36^{*}$ & $\begin{array}{l}59.13 \pm \\
6.14^{*}\end{array}$ & $37.25 \pm 0.21^{*}$ & $\begin{array}{l}34.06 \pm \\
1.28^{*}\end{array}$ \\
\hline 4000 & $42.33 \pm 3.98^{*}$ & $\begin{array}{l}88.50 \pm \\
0.37^{*}\end{array}$ & $55.99 \pm 1.03^{*}$ & $\begin{array}{l}46.02 \pm \\
0.86^{*}\end{array}$ \\
\hline
\end{tabular}

Gallic acid

6.25

$$
\begin{array}{ll}
32.13 \pm 5.48^{*} & - \\
- & 85.77 \pm \\
& 4.50^{*}
\end{array}
$$

Catechin

0.3

EDTA

62.5

$$
\begin{array}{ll}
-\quad-\quad 52.27 \pm 6.27^{*}
\end{array}
$$$$
-
$$

"statistically significance $(P<0.05)$ when compared to control (without extract) ${ }^{a} N D$ not detected

concentration tested $(400 \mu \mathrm{g} / \mathrm{mL})$ in the study. Higher concentration of MUM265 extract was not used for further investigation due to the nature of the extract as its solubility limit posed a challenge for the in vitro experimental set-up.

In addition to measuring cell viability via MTT assay, morphological evaluation of the cancer cells was performed to investigate the effect of the extract on the appearance of the cells. As depicted in Fig. 4, treatment with Streptomyces sp. MUM265 extract visibly altered the cell

Table 4 Pearson's correlation coefficients between TPC and antioxidant activities of Streptomyces sp. MUM265 extract

\begin{tabular}{ll}
\hline Antioxidant activities & Phenolic content \\
\hline DPPH radical scavenging activity & $r=0.941^{\mathrm{a}}$ \\
ABTS radical scavenging activity & $r=0.982^{\mathrm{a}}$ \\
SOD-like activity & $r=0.991^{\mathrm{a}}$ \\
Metal-chelating activity & $r=0.980^{\mathrm{a}}$
\end{tabular}

${ }^{\mathrm{a}}$ Correlation is significant at the 0.05 level morphology of the viable Caco-2 cells. The untreated Caco-2 cells appeared polygonal shaped with some vesicle-like structures (a), however majority of the treated cells showed abnormal morphological features. Treatment with MUM 265 extract caused rounding and detachment of Caco-2 cells. Additionally, cell shrinkage with reduced cytoplasm mass was also observed (indicated by arrows) upon treatment as depicted in Fig. $4 \mathrm{~d}$.

Effect of MUM265 extract on DNA content of Caco-2 cells Intranucleosomal DNA fragmentation is a major hallmark of apoptosis $[55,56]$. Thus, we assessed the effect of treatment with MUM265 extract on DNA content of PI-stained Caco-2 cells using flow cytometry. PI is a fluorescent dye that binds stoichiometrically to nucleic acids [57]; and as fluorescence emission is proportional to DNA content of the cells, it allows the analysis of a cell population's replication state. Hence, cells undergoing apoptosis can be determined from the DNA content histograms as those with lower fluorescent signal due to the low molecular weight of DNA fragments present in these cells compared to the G1 cells [56]. Upon exposure to MUM265 extract for $24 \mathrm{~h}$, the percentage of Caco-2 cells in G0/G1 phases decreased with a concomitant increase of cells in the sub- $G_{1}$ phase (Fig. 5).

\section{Effect of MUM265 extract on mitochondrial membrane potential}

JC-1 dye exhibits variable characteristics when bound to the membrane of apoptotic cells versus non-apoptotic cells. In non-apoptotic cells, JC-1 dye appears in aggregate form emitting orange fluorescence at $590 \mathrm{~nm}$ when bound on polarized mitochondrial membrane with high membrane potential; but exists in monomeric form that emits green fluorescence at $527 \mathrm{~nm}$ in cells with disrupted mitochondrial potential [58]. The result of flow cytometry showed that treatment of Caco-2 cells with MUM265 extract resulted in the increase of green-fluorescence-positive cells, as shown in the P2 region (Fig. 6). As compared to untreated Caco-2 cells (control) $(0.5 \%$ DMSO), a significant decrease $(p<0.05)$ in the ratio of orange-green fluorescence intensity was observed in all concentrations of MUM265 extract tested, indicating depolarization of mitochondrial membrane potential (Fig. 6). Therefore, this result suggested that the MUM265 extract induced cell apoptosis by causing the collapse of mitochondrial membrane potential (MMP) in Caco-2 cells. Taken together, the result of MTT assay is consistent with the observed reduced MMP and accumulated sub- $\mathrm{G}_{1}$ cell population in Caco- 2 cells exposed to MUM265 extract, suggesting that the reduced cell viability of Caco-2 cells upon MUM265 extract treatment is the result of an apoptosis-inducing effect. 


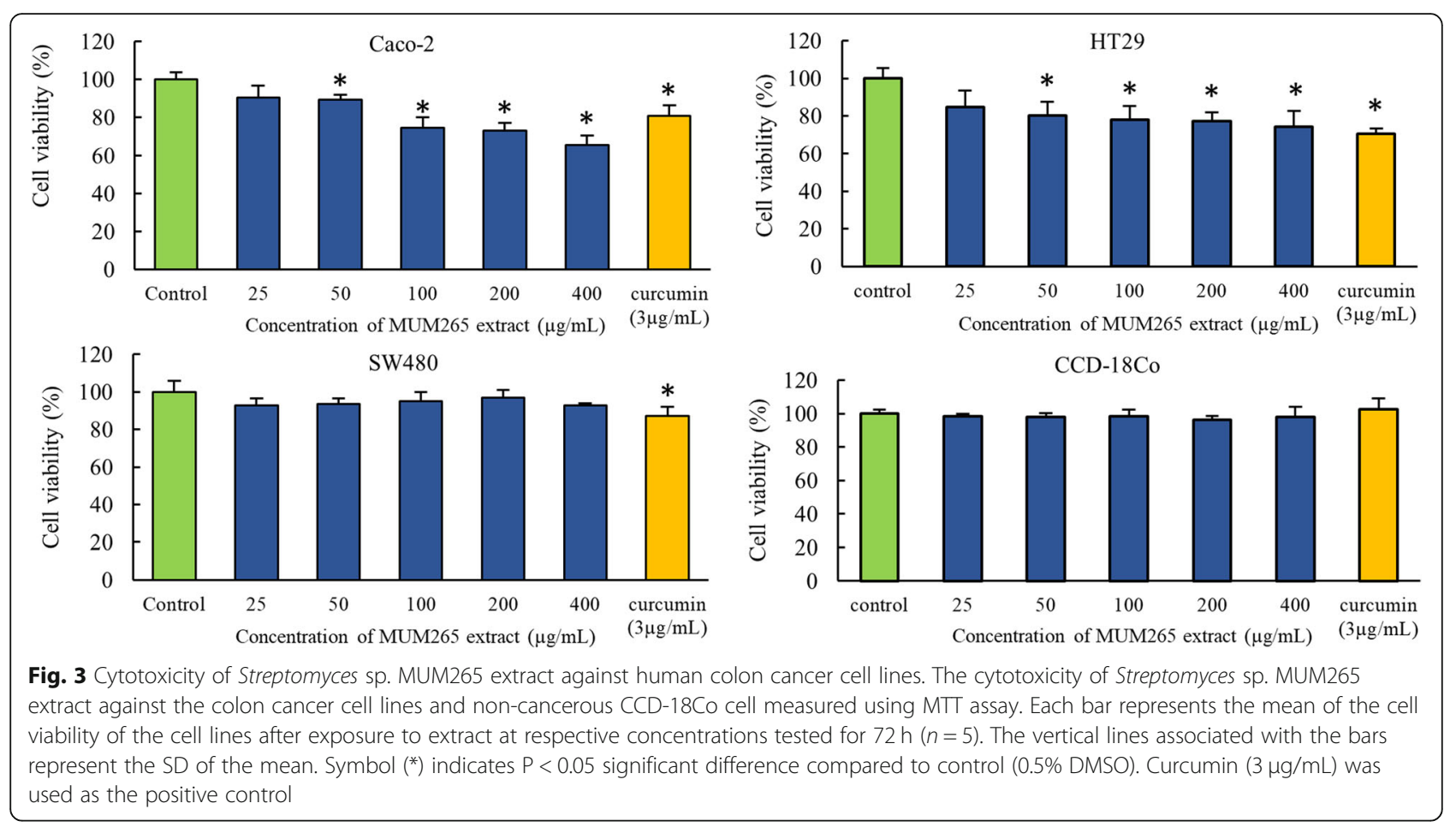

\section{GC-MS profiling of MUM265 extract}

In order to identify some of the chemical constituents potentially responsible for the observed antioxidant and cytotoxic effects, the Streptomyces sp. MUM265 extract was subjected to GC-MS analysis. Our analysis detected a variety of compounds including hydrocarbons, alcohols, phenolics and cyclic dipeptides present in the complex mixturethat is Streptomyces sp. MUM265 extract. Table 5 lists the detailed information of the identified chemical constituents. Figure 7 depicts the chemical
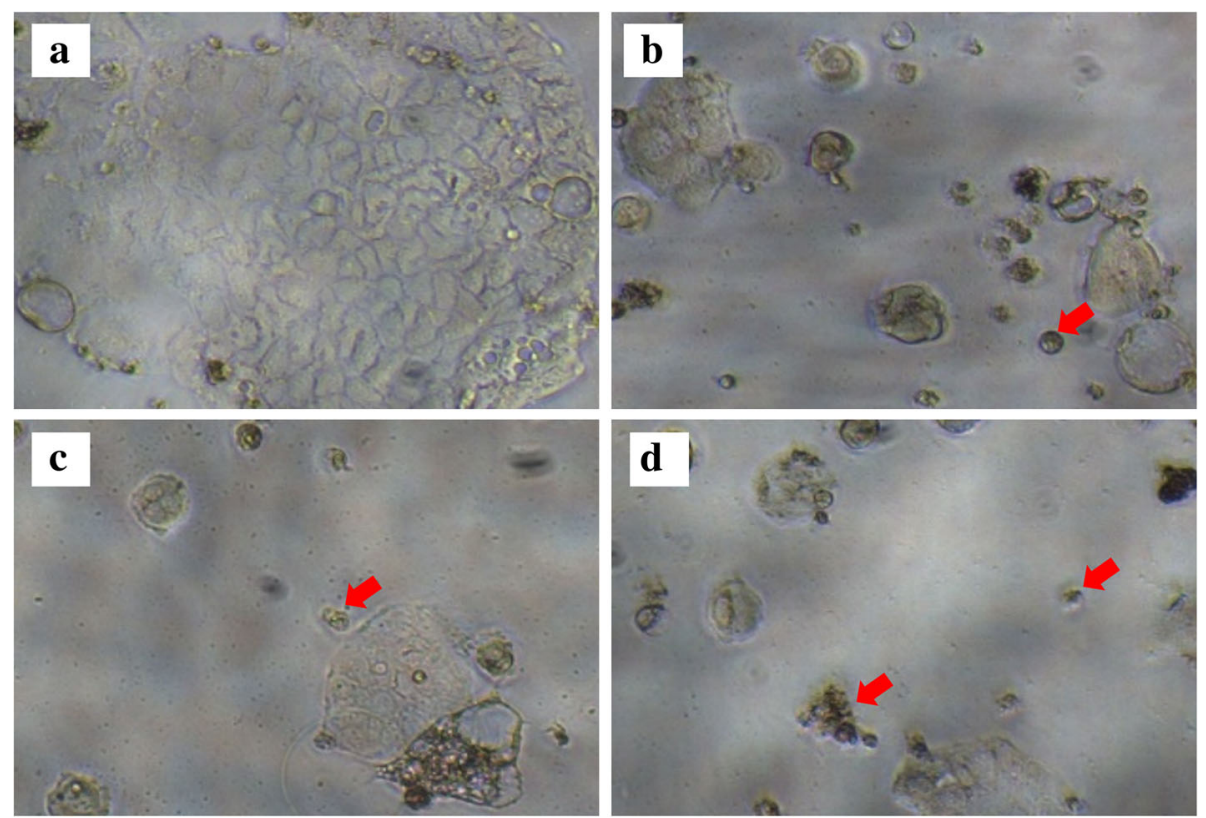

Fig. 4 Morphology of Caco-2 cells after treatment with and without Streptomyces sp. MUM265 extract. Comparison of the morphological features of Caco-2 after the $72 \mathrm{~h}$ incubation without Streptomyces sp. MUM265 extract (0.5\% DMSO) (a) and with the extract (b, c and $\mathbf{d})$ observed under an inverted microscope with objective lens $\times 40$. Arrow indicates the abnormal morphological features resulted from the cytotoxic effect of MUM265 extract (b, $\mathbf{c}$ and $\mathbf{d})$ 


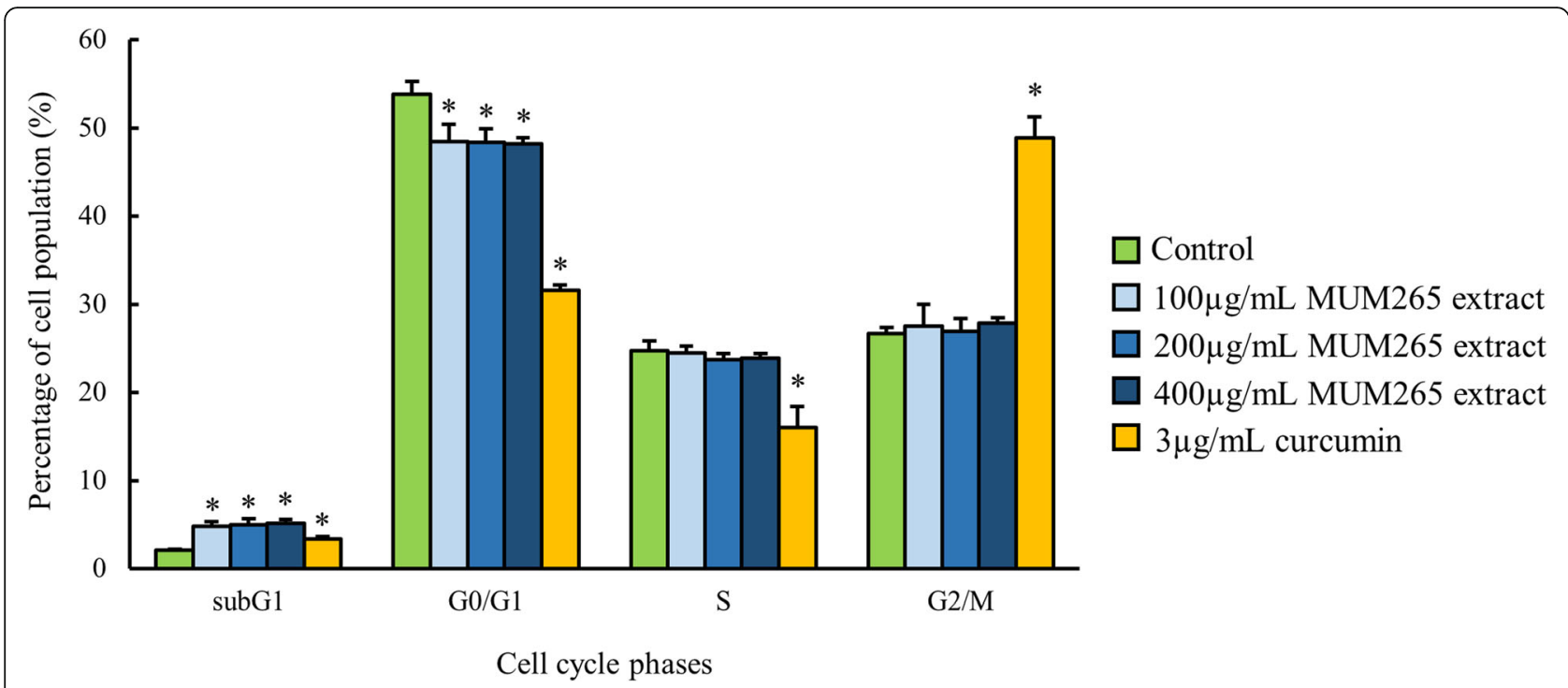

Fig. 5 Effect of MUM265 extract on DNA distribution pattern of Caco-2 cells. PI fluorescent intensity was analyzed using flow cytometry. DNA distribution in different phases of cells followed by $24 \mathrm{~h}$ exposure to extract concentrations ranging from $100 \mu \mathrm{g} / \mathrm{mL}$ to $400 \mu \mathrm{g} / \mathrm{mL}$. The data represents mean \pm S.D. of quadruplicates $(n=4)$. Symbol $\left(^{*}\right)$ indicates $p<0.05$ significant difference compared to control $(0.5 \%$ DMSO). Curcumin $(3 \mu \mathrm{g} / \mathrm{mL})$ was used as positive control

structures of the constituents. In addition, the mass spectrum of the constituents (1-12) identified from the GC-MS analysis are provided (see Additional file 1).

\section{Discussion}

According to Goodfellow [59], it is important to acquire data both from DNA-based methods as well as phenotyping in order to provide a sound basis for the taxonomy of the prokaryotes, especially for the genus Streptomyces. This is because studies have demonstrated that strains in the genus Streptomyces which have high 16SrRNA gene similarity may still display highly varied phenotypic characteristics with regard to their biochemical profiles and carbon source utilization patterns [14, 60]. Therefore, in depth evaluation of biochemical and physiological characteristics of strain MUM265 were conducted to complement the results of phylogenetic analysis, with the aim of providing a better understanding of this strain. The 16S rRNA gene phylogenetic analysis indicated that strain MUM265 does indeed belong to the genus Streptomyces. It grows between $\mathrm{pH} 6.0$ and 7.0 (optimum at $\mathrm{pH} 7$ ), 0 to $6 \% \mathrm{NaCl}$ concentration (optimum 2\%) and temperatures between 20 to $40^{\circ} \mathrm{C}$ (optimum at $36^{\circ} \mathrm{C}$ ). These findings are expected given that these organisms inhabit mangrove environments, which experience daily exposure to tidal inundation with continuously changing salinity and temperature of sediments [61, 62], making a wide range of tolerance to variable conditions of salinity and temperature essential for the survival of this strain. Singh [63] demonstrated that the Biolog Microplate assay not only provides the substrate utilization and growth fingerprint of the test organism but can also be correlated with the production of secondary metabolites with specific bioactivity through additional biological testing and chemical analysis of the extract prepared from each well. In addition, metabolic profile data of strain MUM265 permits the formulation of fermentation media suitable for higher titers and feeding studies [63]. Therefore, this data will be useful in future work on medium optimization which has significant implications on cost in large scale production, as it would facilitate cost saving by enabling the selection of the most cost-effective carbon sources as a substrate. Oxidative stress is a factor that is commonly implicated in the pathogenesis of cancer. Oxidative stress refers to a condition where excessive levels of reactive oxygen species (ROS) are present to such an extent that they overwhelm the body's antioxidant defense system [64]. ROS are produced by all living organisms as by-products of many normal metabolic functions [65] including the mitochondrial respiratory chain [66], neutrophil-mediated respiratory burst in response to microbial infection, [67] and lipid metabolism in peroxisomes [68]; however, these molecules are highly reactive and can damage cell structures such as carbohydrates, nucleic acids, lipids, and proteins and alter their functions. Therefore, maintaining adequate antioxidant levels within the body to maintain a favourable oxidant/antioxidant balance is an important strategy in the prevention of carcinogenesis; plants have been the focus of recommended antioxidant sources so far $[69,70]$, but recent work - including this study - support the idea that 


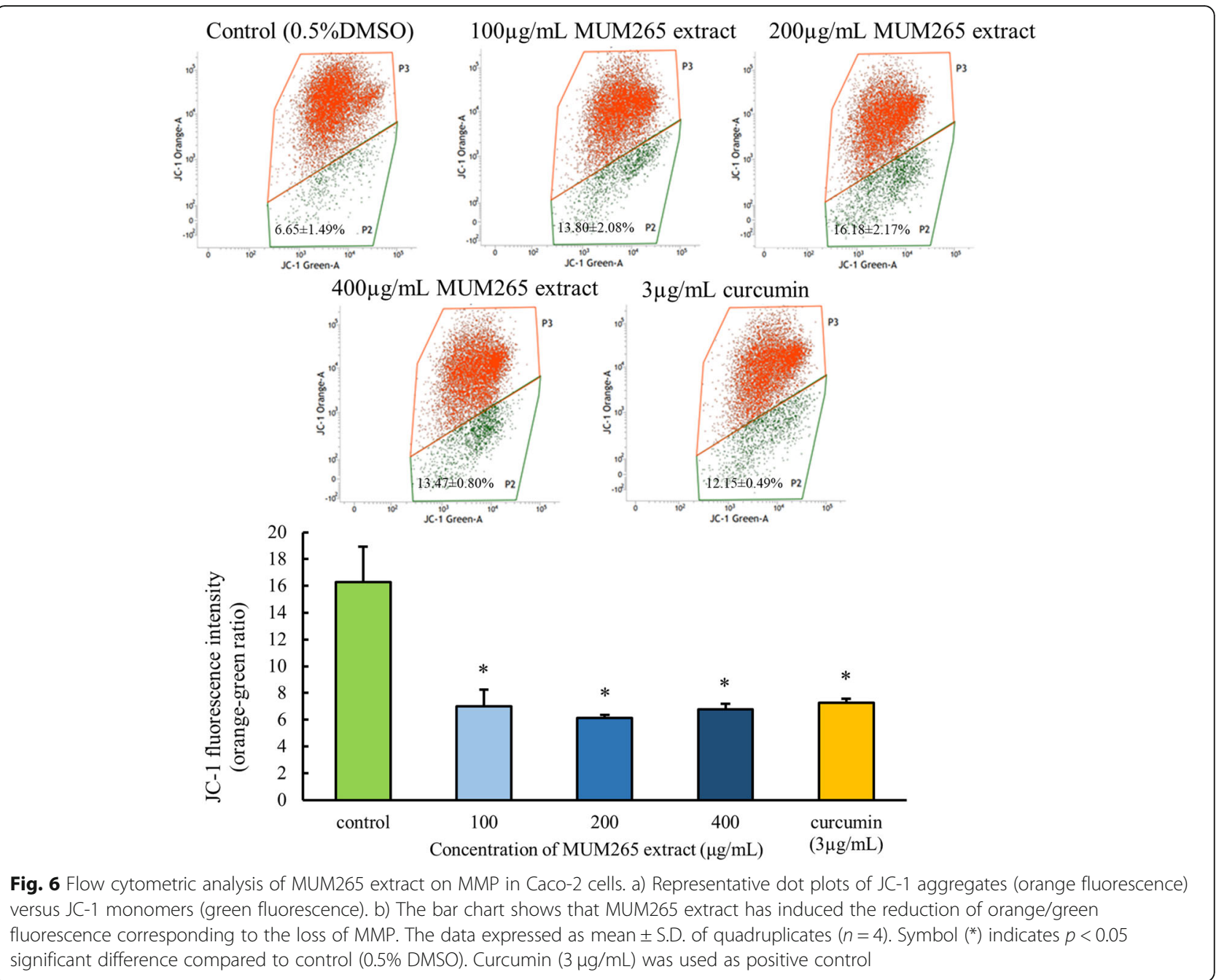

microorganisms represent an as yet untapped source of potent antioxidants $[16,29,71]$.

Oxidation is a very complex process which may occur through a variety of mechanisms [72]; as a result antioxidants may also exert their effects through a variety of pathways. A natural extract could potentially contain a multitude of antioxidants [73] - including phenolic compounds and metal chelators- all of which may have unique mechanisms of action. As a result, it was necessary to utilize a variety of antioxidant assays to gain a better overall picture of the antioxidative power of MUM265 extract; with the assays selected based on the likely mechanisms identified from the existing knowledge/literature. Our results suggest that Streptomyces sp. MUM265 extract is a good source of compounds to be developed into antioxidants with dual functions, such as scavenging of free-radicals as well as simultaneously chelating metal ions. This is perhaps unsurprising as these organisms inhabit an extreme environment where they are constantly exposed to abiotic stresses such as high salinity, drought, hypoxia and high ultraviolet radiation [74] and as a result would have needed to develop survival mechanisms in the form of the ability to produce antioxidative metabolites in order to neutralize the environment induced oxidative stress [8]. It is our belief that our findings suggest that Streptomyces sp. MUM265 extract has the potential to be used as a chemopreventive agent based on its antioxidant properties.

As an extension to this, we chose to further investigate the cytotoxic effects of MUM265 extract against cancer cells - specifically, against a range of human colon cell lines. We chose to test the extract against a variety of cell lines as each has a unique genetic makeup which may result in variable susceptibility or resistance to the extract. This is likely to be the underlying reason for the differential cytotoxicity observed in the various cell lines during the study following exposure to MUM265 extract. Genetic difference between the cell lines have previously been documented - for example different cell lines possess different variants of the KRAS gene where HT29 and Caco-2 possess 
Table 5 Chemical constituents identified in of Streptomyces sp. MUM265 extract

\begin{tabular}{|c|c|c|c|c|c|}
\hline No. & $\begin{array}{l}\text { Constituents } \\
\text { \{synonyms\} }\end{array}$ & $\begin{array}{l}\text { Retention time } \\
(\mathrm{min})\end{array}$ & $\begin{array}{l}\text { Molecular } \\
\text { formula }\end{array}$ & $\begin{array}{l}\text { Molecular Weight } \\
\text { (MW) }\end{array}$ & $\begin{array}{l}\text { Similarity } \\
(\%)\end{array}$ \\
\hline 1 & $2(5 \mathrm{H})$-furanone & 13.844 & $\mathrm{C}_{4} \mathrm{H}_{4} \mathrm{O}_{2}$ & 84 & 90 \\
\hline 2 & 2-ethyl hexan-1-ol & 21.466 & $\mathrm{C}_{8} \mathrm{H}_{18} \mathrm{O}$ & 130 & 83 \\
\hline 3 & Benzyl alcohol & 21.615 & $\mathrm{C}_{7} \mathrm{H}_{8} \mathrm{O}$ & 108 & 74 \\
\hline 4 & 1-Dodecene & 27.348 & $\mathrm{C}_{12} \mathrm{H}_{24}$ & 168 & 83 \\
\hline 5 & Phenol, 2,4-bis(1,1-dimethylethyl)- & 44.440 & $\mathrm{C}_{14} \mathrm{H}_{22} \mathrm{O}$ & 206 & 95 \\
\hline 6 & Benzophenone & 48.725 & $\mathrm{C}_{13} \mathrm{H}_{10} \mathrm{O}$ & 182 & 90 \\
\hline 7 & $\begin{array}{l}\text { (3R,8aS)-3-Methyl-1,2,3,4,6,7,8, 8a-octahydropyrrolo[1,2-a]pyrazine- } \\
\text { 1,4-dione } \\
\{\text { Cyclo(L-Pro-D-Ala)\} }\end{array}$ & 51.592 & $\mathrm{C}_{8} \mathrm{H}_{12} \mathrm{~N}_{2} \mathrm{O}_{2}$ & 168 & 90 \\
\hline 8 & $\begin{array}{l}\text { Pyrrolo[1,2-a]pyrazine-1,4-dione, hexahydro- } \\
\{\text { Cyclo(Gly-Pro)\} }\end{array}$ & 53.131 & $\mathrm{C}_{7} \mathrm{H}_{10} \mathrm{~N}_{2} \mathrm{O}_{2}$ & 154 & 96 \\
\hline 9 & $\begin{array}{l}\text { Octahydro-5H,10H-dipyrrolo[1,2-a:1'2'-d]pyrazine-5,10-dione } \\
\text { \{Cyclo(Pro-Pro)/3,9-diazatricyclo[7.3.0.0(3,7)]dodecan-2,8-dione\} }\end{array}$ & 59.248 & $\mathrm{C}_{10} \mathrm{H}_{14} \mathrm{~N}_{2} \mathrm{O}_{2}$ & 194 & 64 \\
\hline 10 & $\begin{array}{l}\text { Pyrrolo[1,2-a]pyrazine-1,4-dione, hexahydro-3-(2-methylpropyl)- } \\
\text { \{Cyclo(Leu-Pro)/1,4-diaza-2,5-dioxo-3-isobutyl bicyclo[4.3.0]nonane\} }\end{array}$ & 59.340 & $\mathrm{C}_{11} \mathrm{H}_{18} \mathrm{~N}_{2} \mathrm{O}_{2}$ & 210 & 83 \\
\hline 11 & $\begin{array}{l}\text { Pyrrolo[1,2-a]pyrazine-1,4-dione,hexahydro-3-(phenylmethyl)- } \\
\text { Cyclo(Phe-Pro) }\end{array}$ & 72.054 & $\mathrm{C}_{14} \mathrm{H}_{16} \mathrm{~N}_{2} \mathrm{O}_{2}$ & 244 & 93 \\
\hline 12 & Phenol, 2,2'-methylenebis[6-(1,1-dimethylethyl)-4-methyl- & 73.513 & $\mathrm{C}_{23} \mathrm{H}_{32} \mathrm{O}_{2}$ & 340 & 95 \\
\hline
\end{tabular}

wild-type KRAS while SW480 is known to have a mutated KRAS oncogene [75]. Based on this finding, it could be postulated that HT29 and Caco-2 colon cancer cells (with wild-type KRAS) are more sensitive toward MUM265 extract than colon cancer cell SW480 (with mutated KRAS oncogene) which was resistant toward MUM265 extract.

Although $\mathrm{ED}_{50}$ was not achieved by the concentrations of MUM265 extract tested in this study, MUM265 extract seems to result in the activation of various pathways that result in apoptosis of vulnerable cells such as Caco- 2 cells which showed morphological changes post exposure which were consistent with the activation of apoptosis-related pathways. Additional evidence came in the form of accumulation of sub-G1 cell population which indicated the presence of an increased number of cells with reduced DNA content or fragmented DNA and suggested that the MUM265 extract induced DNA damage in Caco-2 cells, which subsequently led to apoptosis. MUM265 extract also appears to induce loss of MMP in Caco-2 cells; with MMP being a substance which regulates the selectivity and permeability of the mitochondrial membrane towards various substances as well as to maintain mitochondrial functionality $[76,77]$. The increased membrane permeability resulting from loss of MMP is also associated with the release of

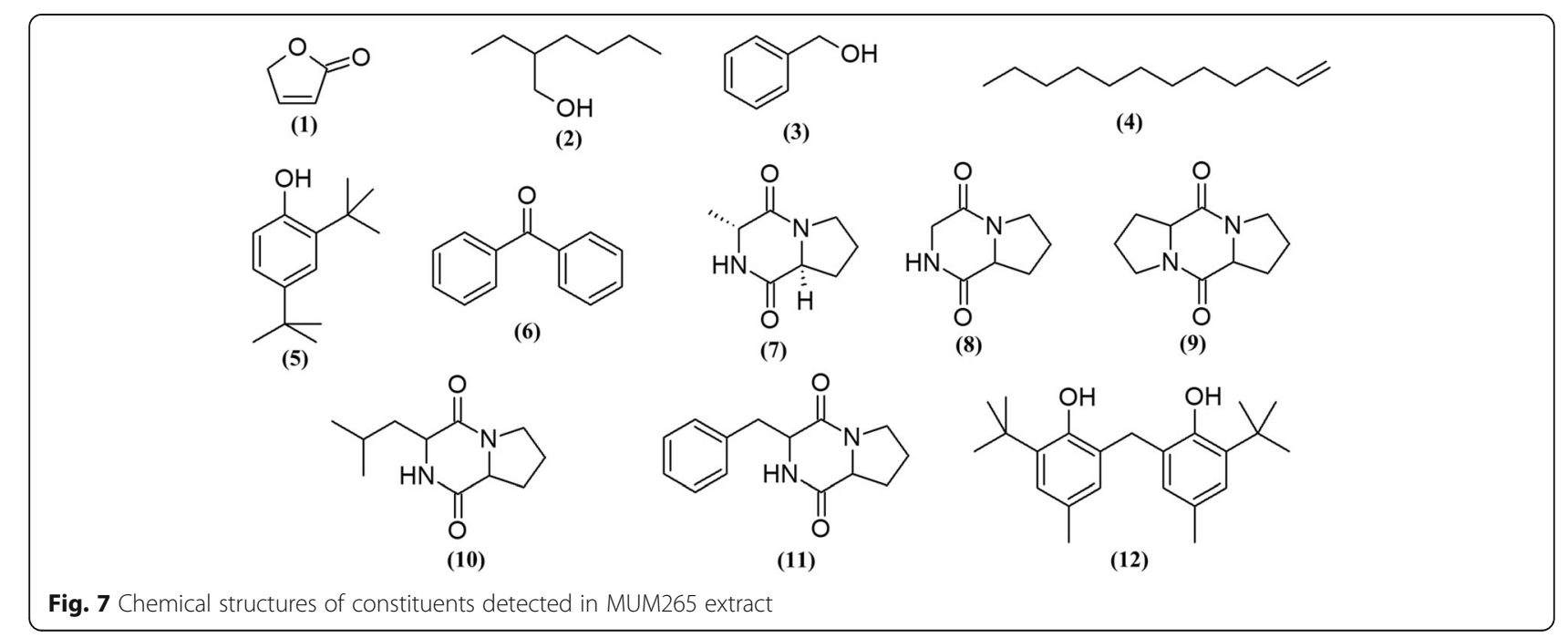


soluble proteins that serve as activators for the caspases and endonucleases responsible for most forms of apoptosis [78]. While all these in combination support our postulation that MUM265 extract's cytotoxic effect may be mediated via mitochondrial-dependent apoptotic pathways, further mechanistic studies on mitochondrialdependent cell death pathway would be needed to obtain a clearer understanding of the molecular targets of MUM265 extract.

It is noteworthy that GC-MS analysis has contributed significantly in the bioprospecting of natural products isolated from Streptomyces bacteria [28, 79-82]. Most of the compounds detected by GC-MS in MUM265 extract have been also reported previously in Streptomyces sp. extracts, such as 2(5H)-furanone (1) [83], 2-ethyl hexan-1-ol (2) [84], benzyl alcohol (3) [85], 1-dodecene (4) [86], phenol,2,4-bis(1,1-dimethylethyl)- (5) [82, 87], benzophenone (6) [88, 89], pyrrolo[1,2-a]pyrazine-1,4-dione, hexahydro- (8) [16], pyrrolo[1,2-a]pyrazine-1,4-dione, hexahydro-3-(2-methylpropyl)- (10) [90], pyrrolo[1,2-a]pyrazine-1,4-dione,hexahydro-3-(phenylmethyl)- (11) [90], phenol, 2,2'-methylenebis [6-(1,1-dimethylethyl)-4-methyl- (12).

The detection of phenolic compounds in the Streptomyces MUM265 extract is in concordance with the findings of the total phenolic content estimation. The phenolic compounds were phenol,2,4-bis(1,1-dimethylethyl)- (5) and phenol, 2,2'-methylenebis[6-(1,1-dimethylethyl)-4-methyl- (12). Given their well-recognized role as antioxidants, phenolic compounds reduce free radicals by means of their hydrogen-donating or electron transferring abilities [91, 92]. Thus, it can be suggested that these phenolic compounds could contribute to the overall antioxidant capacity of Streptomyces sp. MUM265 extract, which possess capability to scavenge free-radicals and chelate metal ions. Previously, a study revealed the detection of phenol,2,4-bis(1,1-dimethylethyl)- (5) in the crude extract of a Streptomyces sp. isolated from vermicompost samples. Interestingly, the crude extract also demonstrated potent antioxidant properties and cytotoxicity against cervical cancer cells [93].

Several cyclic dipeptides have been detected from the extract, including cyclo(L-Pro-D-Ala) or (3R,8aS)-3-methy1-1,2,3,4,6,7,8,8a-octahydropyrrolo[1,2-a]pyrazine-1,4-dione (7), cyclo(Gly-Pro) or pyrrolo[1,2-a]pyrazine-1,4-dione, hexahydro- (8), cyclo(Pro-Pro) or octahydro-5H,10H-dipyrrolo [1,2-a:1'2'-d]pyrazine-5,10-dione (9), cyclo(Leu-Pro) or pyrrolo[1,2-a]pyrazine-1,4-dione, hexahydro-3-(2-methylpropyl)- (10) and cyclo(Phe-Pro) or pyrrolo[1,2-a]pyrazine-1,4-dione,hexahydro-3-(phenylmethyl)- (11) in the present study. Cyclic dipeptides are known to be a group of the simplest peptide derivatives [94]. Recently, these compounds have also often been reported in studies of fermentation culture of microbes [18, 95, 96]. Extracts of Streptomyces sp. which contain these cyclic dipeptides have previously been demonstrated to exhibit promising antioxidant activity [16, 29]. Besides the detection of cyclic dipeptides in Streptomyces, pyrrolo[1,2-a]pyrazine-1,4-dione, hexahydro- (8) was also reported from sponge associated $\mathrm{Ba}$ cillus sp. and it was shown to reduce oxidative damage by radicals [97]. Furthermore, the extract of Micrococcus lutues containing both pyrrolo[1,2-a]pyrazine-1,4-dione, hexahydro(8) and pyrrolo[1,2-a]pyrazine-1,4-dione, hexahydro-3(2-methylpropyl)- (10) was demonstrated to exert cytotoxic effect on HCT15 [98]. Additionally, cyclo(L-Pro-L-Phe) (11), one of the cyclic dipeptides present in a mixture isolated from Pseudomonas aeruginosa PAO1 strain was shown to promote cell death in HeLa and Caco-2 cells in a dose-dependent manner. The study also suggested that the mixture - which contained cyclic dipeptides - mediated the apoptotic pathway related inhibition of cell proliferation [96]. Similarly, cyclo(L-Pro-L-Phe) (11) isolated from Bacillus species also caused apoptosis in U-87MG cells from human glioblastoma through AKT1 inactivation by down-regulating the phosphorylation of AKT1 serine/theorine kinase at 0.01 $\mathrm{mg} / \mathrm{mL}[95,99]$. These findings correlate well with the cytotoxic effect of MUM265 extract against Caco-2 cells, suggesting that the cyclic dipeptides present in the extract could have induced apoptosis in Caco-2 cells. Perhaps purification of these compounds could be performed in future to evaluate their efficacy by determining the ED50 against colon cancer cells.

The GC-MS chemical profiling of MUM265 extract detected chemical constituents with well recognized antioxidant and cytotoxic properties. These findings suggest that these chemical constituents could have contributed to both antioxidant capacity and cytotoxic properties of Streptomyces sp. MUM265 extract. On the whole, the detection of these groups of compounds in MUM265 extract further strengthens the prospect of mangrove derived Streptomyces being recognized as a producer of compounds that may be potential drug candidates for chemoprevention of cancer.

\section{Conclusions}

The extensive characterization of Streptomyces sp. MUM265 conducted in this study indicates it is a potential source of novel industrial and pharmaceutical products. MUM265 has several features that make it highly attractive from an industry view point, chiefly its good salt and temperature tolerance, as well as its secretion of industrially valuable enzymes and production of bioactive compounds. We believe that our findings regarding the behavior and substrate utilization of the strain and its bioactivities, are potentially key to further manipulation to exploit the biosynthetic output of the strain as they will aid with creation of conditions stimulating maximum efficiency in producing the desired compounds. The antioxidant and anti-colon cancer 
properties demonstrated in our work make this organism well worth studying further. The MUM265 extract exhibits antioxidant properties including DPPH radical scavenging, ABTS radical scavenging, superoxide anion radical scavenging and metal chelating activity. In addition, MUM265 extract induces depolarization of mitochondrial membrane potential and DNA fragmentation of Caco-2 cells, suggesting apoptosis-inducing properties of MUM265 extract in colon cancer cells. This raises the exciting possibility that further exploration of the biochemical properties and mechanisms of action of the various compounds in the extract from this organism will reveal new mechanisms of action for chemopreventive and anti-cancer drug development.

\section{Methods}

\section{Isolation of strain MUM265 from mangrove soil}

The isolation of strain MUM265 was conducted on a mangrove soil sample of Kuala Selangor mangrove forest, Malaysia $\left(3^{\circ} 21^{\prime} 45.8^{\prime \prime} \mathrm{N} 101^{\circ} 18^{\prime} 4.5^{\prime \prime} \mathrm{E}\right)$ in Jan 2015. The soil samples were collected from the soil layer within the top $20 \mathrm{~cm}$ depth with the removal of surface to a 2 to $3 \mathrm{~cm}$ depth, stored in sterile plastic bags and kept at $-20{ }^{\circ} \mathrm{C}$. The soil samples were air-dried prior to grinding with mortar and pestle. Wet heat pretreatment of the soil samples was performed for 15 mins at $50{ }^{\circ} \mathrm{C}$ as described by Takahashi et al. [100]. Ten times dilution of the pre-treated soil samples were spread onto the ISP 2 isolation medium to which cycloheximide $(25 \mu \mathrm{g} / \mathrm{ml})$ and nystatin $(10 \mu \mathrm{g} / \mathrm{ml})$ had been added, and incubated at $28^{\circ} \mathrm{C}$ for 14 days [101]. Pure culture of strain MUM265 was isolated and maintained on slants of ISP 2 agar at $28^{\circ} \mathrm{C}$ and in $20 \%(\mathrm{v} / \mathrm{v})$ glycerol stock at $-20^{\circ} \mathrm{C}$.

\section{Genomic DNA extraction, 16S rRNA PCR and phylogenetic analysis}

Genomic DNA extraction was performed on strain MUM265 prior to $16 \mathrm{~S}$ rRNA sequencing [8]. The $16 \mathrm{~S}$ rRNA gene was amplified by PCR according to the method of Lee et al. [14] using the primer pair 27F-1492R [9]. The PCR reactions were conducted based on the protocol for SolGent ${ }^{\text {ti }} 2 \mathrm{X}$ Taq PLUS PCR Smart mix using the Kyratex PCR Supercycler (Kyratec, Australia). The optimized cycling conditions were as follows: (i) $95^{\circ} \mathrm{C}$ for $5 \mathrm{~min}$, (ii) 35 cycles of $94^{\circ} \mathrm{C}$ for $50 \mathrm{~s}$, $55^{\circ} \mathrm{C}$ for $1 \mathrm{~min}$ and $72{ }^{\circ} \mathrm{C}$ for $1 \mathrm{~min} 30 \mathrm{~s}$; and (iii) $72^{\circ} \mathrm{C}$ for $8 \mathrm{~min}$. CLUSTAL-X software was used to align the $16 \mathrm{~S}$ rRNA gene sequence of strain MUM265 with the $16 \mathrm{~S}$ rRNA sequences of related Streptomyces type strains retrieved from the GenBank/EMBL/DDBJ databases [102]. Phylogenetic trees were built via neighbour-joining algorithm [103] (Fig. 1) using MEGA version 6.0 [104] based on the Kimura's two-parameter model [105]. The EzTaxon-e server (https://www.ezbiocloud.net/)
[106] was used to determine sequence similarity. A 1000 bootstrap resampling based on method of Felsenstein [107] was performed to assess the clade support of the constructed trees topologies.

\section{Phenotypic characteristics}

The colony morphology and phenotypic characteristics of strain MUM265 were examined using different agar media (HiMedia, India) including ISP 2, ISP 3, ISP 4, ISP 5, ISP 6, ISP 7 [101], actinomycetes isolation agar (AIA) [108], starch casein agar (SCA) [109] and nutrient agar [110] for 14 days at $28^{\circ} \mathrm{C}$. The colony color of strain MUM265 was determined with reference to ISCC-NBS color charts [111]. Microscopic evaluation was performed with a light microscope (80i, Nikon) and scanning electron microscope (TM-1000, Hitachi) on 7-14 days culture. Gram staining was conducted [112]. The production of melanoid pigments on ISP7 media was determined as described by Lee et al. [113]. The effect of temperature on the growth of strain MUM265 was assessed on ISP2 agar. The effects of salt concentration and $\mathrm{pH}$ on the growth of strain MUM265 were assessed in tryptic soy broth [29]. Hemolytic activity of strain MUM265 was examined on horse blood agar [114]. Enzymatic tests were performed to test the enzymes produced by strain MUM265 [115]. Antibiotic susceptibility of strain MUM265 was examined using the antibiotic disc diffusion method [116]. Biolog GenIII MicroPlates was used to evaluate the carbon and nitrogen source utilization and chemical sensitivity of the strain (Biolog, USA).

\section{Extract preparation of strain MUM265}

Fermentation of strain MUM265 was performed according to Tan et al. [117] using Han's Fermentation Media 1 (HFM1) (Biomerge, Malaysia). Extraction was conducted on the freeze-dried fermentation product according to Tan et al. [117]. The extract was collected and suspended in dimethyl sulphoxide (DMSO) before further analysis.

\section{Antioxidant activity evaluation of MUM265 extract}

DPPH (2,2-diphenyl-1-picrylhydrazyl) radical scavenging assay was conducted according to the previously described method [16]. The reduced absorbance of DPPH radical was measured at $515 \mathrm{~nm}$ with a microplate reader. The superoxide anion scavenging activity or superoxide dismutase (SOD) like activity of MUM265 extract was examined by employing 19,160 SOD Assay Kit-WST (Sigma Aldrich) with slight modification [29]. The 2,2'-azino-bis(3-ethylbenzothiazoline-6-sulphonic acid) (ABTS) assay was performed as described in Tan et al. [29]. ABTS radical cation $\left(\mathrm{ABTS}^{\bullet}+\right.$ ) was generated by reacting $7 \mathrm{mM}$ ABTS stock solution with $2.45 \mathrm{mM}$ potassium persulphate for $24 \mathrm{~h}$ prior to conducting the assay. The reduction of ABTS radical absorbance was 
measured at $734 \mathrm{~nm}$ with a microplate reader. Metal-chelating activity was measured as described by Tan et al. [118]. The TPC in MUM265 extract was assessed by using Folin-Ciocalteu's reagent method [119]. Meanwhile, the total flavonoid content in MUM265 extract was assessed by the aluminium chloride colorimetric 96 well-microplate method [120].

\section{Cell lines maintenance and growth condition}

Caco-2, HT-29, SW480 and CCD-18Co cell lines were obtained from the American Type Culture Collection (ATCC, Manassas, VA, USA). All cells were cultured in RPMI-1640 (Gibco) supplemented with 10\% fetal bovine serum and $1 \mathrm{x}$ antibiotic-antimycotic (Gibco) at $37^{\circ} \mathrm{C}$ in a $\mathrm{CO}_{2}$ incubator.

\section{Cell treatment and MTT cell viability assay}

The cytotoxic effects of Streptomyces sp. MUM265 extract on human colon cancer cell lines were evaluated using 3-(4,5-dimethylthiazol-2-yl)-2,5-diphenyltetrazolium bromide (MTT) assay based on a previously established method [121]. Cells were seeded into 96-well plate at density of $5 \times 10^{3}$ cells per well and left in incubator overnight. Control cells were treated with $0.5 \%$ DMSO while the concentration of DMSO was maintained at $0.5 \%$ across all treatments with MUM265 extract for the entire series of concentrations ranging from 25 to $400 \mu \mathrm{g} / \mathrm{mL}$. MTT assay was conducted after $72 \mathrm{~h}$ of exposure to the extract. The assay was performed by adding $20 \mu \mathrm{L}$ of MTT solution $(5 \mathrm{mg} / \mathrm{mL})$ to each well and incubated at $37^{\circ} \mathrm{C}$ with $5 \% \mathrm{CO}_{2}$ for $4 \mathrm{~h}$. The medium was removed prior to the dissolution of the formazan product formed using $100 \mu \mathrm{L}$ of DMSO. The amount of MTT-formazan was determined at $570 \mathrm{~nm}$ absorbance with $650 \mathrm{~nm}$ as reference wavelength.

\section{Cell cycle analysis}

DNA content and cell cycle distribution were evaluated using propidium iodide (PI) staining [121]. After exposure to MUM265 extract for $24 \mathrm{~h}$, cells were harvested and washed with $\mathrm{PBS}$ before being fixed with $70 \%$ ice-cold ethanol at $-20^{\circ} \mathrm{C}$ overnight. Fixed cells were washed twice and stained in a buffer containing $25 \mu \mathrm{g} / \mathrm{mL}$ PI, $0.1 \%$ Triton-X-100 and $100 \mu \mathrm{g} / \mathrm{mL}$ RNase A for 30 mins in the dark at room temperature. The PI-stained cells were analyzed using BD FACSVerse ${ }^{\mathrm{Tm}}$ flow cytometer (BD Bioscience, San Jose, CA).

\section{Mitochondrial membrane potential}

JC-1 (5,5',6,6' 'tetrachloro-1,1',3,3' -tetrathylbenzimidazolcarbocyanine iodide) dye from $\mathrm{BD}^{\mathrm{TM}}$ MitoScreen kit ((BD Bioscience, San Jose, CA) was used to evaluate the status of mitochondrial membrane potential of the cells.
After exposure to MUM265 extract for $24 \mathrm{~h}$, cells were harvested and washed twice before analysis using $\mathrm{BD}$ FACSVerse $^{\mathrm{TM}}$ flow cytometer (BD Bioscience, San Jose, CA).

Gas chromatography-mass spectrometry (GC-MS) analysis GC-MS chemical profiling was conducted based on a previously developed protocol [122]. The analysis was conducted using Agilent Technologies $6980 \mathrm{~N}$ (GC) equipped with 5979 Mass Selective Detector (MS), HP-5MS (5\% phenyl methyl siloxane) capillary column of dimensions $30.0 \mathrm{~m} \times 250 \mu \mathrm{m} \times 0.25 \mu \mathrm{m}$ using helium as the carrier gas at $1 \mathrm{~mL} / \mathrm{min}$. The experiment was initiated by maintaining the column temperature at $40{ }^{\circ} \mathrm{C}$ for 10 mins, followed by an increase of $3{ }^{\circ} \mathrm{C}$ per min to $250^{\circ} \mathrm{C}$ and was kept isothermal for $5 \mathrm{~min}$. The MS was operating at $70 \mathrm{eV}$. Comparison of the mass spectral between the detected chemical constituents and the standards available in W9 N11 MS library was performed to identify the chemical constituents present in the extract.

\section{Statistical analysis}

Both antioxidant and cytotoxicity assays were conducted at least in triplicate. Results were expressed in mean \pm standard deviation (SD). The statistical analysis was performed using SPSS software. The difference between the treated and untreated groups was determined by one-way analysis of variance (ANOVA) and Tukey's post hoc analysis. A statistically significant difference was determined when $p \leq 0.05$. Pearson's correlation analysis was used to evaluate the relationship between the phenolic content and the antioxidant activity of the extract [123].

\section{Additional file}

Additional file 1: Table S1. Antibiotic susceptibility test. Figure S1. The mass spectrum of the constituents (1-12) identified from the GC-MS analysis. (a) The mass spectrum of the constituents obtained from MUM265 extract, (b) the mass spectrum of the standard compounds available on W9N11 MS library. (DOCX 559 kb)

\section{Abbreviations \\ ABTS: 2,2'-azino-bis(3-ethylbenzothiazoline-6-sulphonic acid; DPPH: 2,2-diphenyl-1- picrylhydrazyl; GC-MS: Gas chromatography mass spectrometry; ISP: International Streptomyces Project; SOD: Superoxide oxide dismutase; TPC: Total phenolic content}

\section{Acknowledgments}

This work was inspired by Monash PhD Research Training Module which entitled "Bioprospective of microbes with biopharmaceutical potential with bioinformatics and drug discovery platforms".

\section{Funding}

This research was financially supported by PVC Award Grant (Project No. PVC-ECR2016), External Industry Grant (Biotek Abadi - Vote No. GBA-808813), Fundamental Research Grant Scheme (FRGS/1/2013/SKK01/MUSM/03/3), MOSTI eScience funds (Project No. 06-02-10-SF0300) awarded to L.-H. L and External Industry Grant (Biotek Abadi - Vote No. GBA-81811A), MOSTI eScience funds (Project No. 02-02-10-SF0215) awarded to B.H.G in the design of the study and collection, analysis and 
interpretation of data. Furthermore, we also thank University of Malaya Research Grants (PPP grants PG088-2015B and PG089-2015B and JBK grant GA002-2016) awarded to K.-G. C. in providing financial support and facilities.

\section{Availability of data and materials}

The 165 rRNA sequence generated from this research has been deposited in NCBI GenBank under accession number KY656444.

\section{Authors' contributions}

$\mathrm{BH}-\mathrm{G}$ and $\mathrm{L}-\mathrm{HL}$ conceived and designed the experiments; LT-HT performed the experiments; LT-HT analyzed the data; LT-HT, B-HG and L-HL. drafted and wrote the paper; TMK and PP substantially revised, improved and finalized the manuscript; WFY and K-GC contributed by the acquisition of the sequencing data and proofread on the writing. All authors have read, discussed and approved to publish the data in this final manuscript

\section{Ethics approval and consent to participate} Not applicable.

\section{Consent for publication}

Not applicable.

\section{Competing interests}

The authors declare that they have no competing interests.

\section{Publisher's Note}

Springer Nature remains neutral with regard to jurisdictional claims in published maps and institutional affiliations.

\section{Author details}

${ }^{1}$ Institute of Biomedical and Pharmaceutical Sciences, Guangdong University of Technology, Guangzhou 510006, People's Republic of China. ${ }^{2}$ Biofunctional Molecule Exploratory (BMEX) Research Group, School of Pharmacy, Monash University Malaysia, 47500 Bandar Sunway, Selangor Darul Ehsan, Malaysia. ${ }^{3}$ Novel Bacteria and Drug Discovery (NBDD) Research Group, Microbiome and Bioresource Research Strength, Jeffrey Cheah School of Medicine and Health Sciences, Monash University Malaysia, 47500 Bandar Sunway, Selangor Darul Ehsan, Malaysia. ${ }^{4}$ International Genome Centre, Jiangsu University, Zhenjiang, China. ${ }^{5}$ Division of Genetics and Molecular Biology, Faculty of Science, Institute of Biological Sciences, University of Malaya, Kuala Lumpur, Malaysia. ${ }^{6}$ Medical Health and Translational Research Group, Jeffrey Cheah School of Medicine and Health Sciences, Monash University Malaysia, 47500 Bandar Sunway, Selangor Darul Ehsan, Malaysia. ${ }^{7}$ Institute of Pharmaceutical Science, University of Veterinary and Animal Science, Lahore, Pakistan. ${ }^{8}$ Center of Health Outcomes Research and Therapeutic Safety (Cohorts), School of Pharmaceutical Sciences, University of Phayao, Phayao, Thailand.

Received: 9 April 2018 Accepted: 31 January 2019

Published online: 13 February 2019

\section{References}

1. Ferlay J, Soerjomataram I, Dikshit R, Eser S, Mathers C, Rebelo M, Parkin DM, Forman D, Bray F. Cancer incidence and mortality worldwide: sources, methods and major patterns in GLOBOCAN 2012. Int J Cancer. 2015;136(5): E359-86.

2. Pourhoseingholi MA. Epidemiology and burden of colorectal cancer in AsiaPacific region: what shall we do now? Transl Gastrointest Cancer. 2014;3(4): 169-73.

3. Key TJ, Allen NE, Spencer EA, Travis RC. The effect of diet on risk of cancer. Lancet. 2002;360(9336):861-8.

4. Haggar FA, Boushey RP. Colorectal cancer epidemiology: incidence, mortality, survival, and risk factors. Clin Colon Rectal Surg. 2009;22(4):191

5. Watson AJ, Collins PD. Colon cancer: a civilization disorder. Dig Dis. 2011; 29(2):222-8

6. Jennerjahn T, Gilman E, Krauss KW, Lacerda L, Nordhaus I, Wolanski E. Mangrove Ecosystems under Climate Change. In: Mangrove Ecosystems: A Global Biogeographic Perspective. Cham: Springer; 2017. p. 211-44.

7. Azman A-S, Othman I, Velu SS, Chan K-G, Lee L-H. Mangrove rare actinobacteria: taxonomy, natural compound, and discovery of bioactivity. Front Microbiol. 2015;6:856
8. Hong K, Gao A-H, Xie Q-Y, Gao HG, Zhuang L, Lin H-P, Yu H-P, Li J, Yao X-S, Goodfellow M. Actinomycetes for marine drug discovery isolated from mangrove soils and plants in China. Mar Drugs. 2009;7(1):24-44.

9. Lee L-H, Zainal N, Azman A-S, Eng S-K, Goh B-H, Yin W-F, Ab Mutalib N-S, Chan K-G. Diversity and antimicrobial activities of actinobacteria isolated from tropical mangrove sediments in Malaysia. Sci World J. 2014:2014. 698178

10. Azman A-S, Othman I, Fang C-M, Chan K-G, Goh B-H, Lee L-H. Antibacterial, anticancer and neuroprotective activities of rare Actinobacteria from mangrove forest soils. Indian J Microbiol. 2017;57(2):177-87.

11. Ser H-L, Tan W-S, Cheng H-J, Yin W-F, Chan K-G, Ab Mutalib N-S, Goh B-H, Lee L-H. Draft genome of starch-degrading actinobacterium, Microbacterium mangrovi MUSC 115T isolated from intertidal sediments. Prog Drug Discov Biomed Sci. 2018;1(1):1-3.

12. Ser H-L, Yin W-F, Chan K-G, Ab Mutalib N-S, Lee L-H. Genome sequence of Novosphingobium malaysiense strain MUSC 273T, novel alpha- proteobacterium isolated from intertidal soil. Prog Microbes Mol Biol. 2018;1(1):1-2

13. Hu H, Lin H-P, Xie Q, Li L, Xie X-Q, Sun M, Hong K. Streptomyces shenzhenensis sp. nov., a novel actinomycete isolated from mangrove sediment. Antonie Van Leeuwenhoek. 2011;100(4):631-7.

14. Lee L-H, Zainal N, Azman A-S, Eng S-K, Ab Mutalib N-S, Yin W-F, Chan K-G Streptomyces pluripotens sp. nov., a bacteriocin-producing streptomycete that inhibits meticillin-resistant Staphylococcus aureus. Int J Syst Evol Microbiol. 2014;64(Pt 9):3297-306.

15. C-y R, Zhang L, Ye W-w, Xie X-c, Srivibool R, Duangmal K, Pathom-aree W, Deng Z-x, Hong K. Streptomyces ferrugineus sp. nov., isolated from mangrove soil in Thailand. Antonie Van Leeuwenhoek. 2015;107(1):39-45.

16. Ser H-L, Palanisamy UD, Yin W-F, Malek A, Nurestri S, Chan K-G, Goh B-H Lee $\mathrm{L}-\mathrm{H}$. Presence of antioxidative agent, Pyrrolo [1, 2-a] pyrazine-1, 4-dione, hexahydro-in newly isolated Streptomyces mangrovisoli sp. nov. Front Microbiol. 2015;6:854.

17. Ser HL, Zainal N, Palanisamy UD, Goh BH, Yin WF, Chan KG, Lee LH. Streptomyces gilvigriseus sp. nov., a novel actinobacterium isolated from mangrove forest soil. Antonie Van Leeuwenhoek. 2015;107(6):1369-78.

18. Ser H-L, Palanisamy UD, Yin W-F, Chan K-G, Goh B-H, Lee L-H. Streptomyces malaysiense sp. nov:: A novel Malaysian mangrove soil actinobacterium with antioxidative activity and cytotoxic potential against human cancer cell lines. Sci Rep. 2016:6, 24247.

19. Zainal N, Ser H-L, Yin W-F, Tee K-K, Lee L-H, Chan K-G. Streptomyces humi sp. nov., an actinobacterium isolated from soil of a mangrove forest. Antonie Van Leeuwenhoek. 2016;109(3):467-74.

20. Ser H-L, Tan LT-H, Palanisamy UD, Abd Malek SN, Yin W-F, Chan KG, Goh $\mathrm{BH}$, Lee L-H. Streptomyces antioxidans sp. nov., a novel mangrove soil actinobacterium with antioxidative and neuroprotective potentials. Front Microbiol. 2016:7:899.

21. Law JW-F, Ser H-L, Duangjai A, Saokaew S, Bukhari SI, Khan TM, Ab Mutalib N-S, Chan K-G, Goh B-H, Lee L-H. Streptomyces colonosanans sp. nov., a novel actinobacterium isolated from Malaysia mangrove soil exhibiting antioxidative activity and cytotoxic potential against human colon cancer cell lines. Front Microbiol. 2017:8, 877

22. Berdy J. Bioactive microbial metabolites. J Antibiot. 2005:58(1):1-26.

23. Tan LT-H, Chan K-G, Lee L-H, Goh B-H. Streptomyces bacteria as potential probiotics in aquaculture. Front Microbiol. 2016:7:79.

24. Grimm A, Madduri K, Ali A, Hutchinson C. Characterization of the Streptomyces peucetius ATCC 29050 genes encoding doxorubicin polyketide synthase. Gene. 1994;151(1):1-10.

25. Du L, Sánchez C, Chen M, Edwards DJ, Shen B. The biosynthetic gene cluster for the antitumor drug bleomycin from Streptomyces verticillus ATCC15003 supporting functional interactions between nonribosomal peptide synthetases and a polyketide synthase. Chem Biol. 2000;7(8):623-42.

26. Brautaset $T$, Sekurova ON, Sletta H, Ellingsen TE, Strøm AR, Valla S, Zotchev SB. Biosynthesis of the polyene antifungal antibiotic nystatin in Streptomyces noursei ATCC 11455: analysis of the gene cluster and deduction of the biosynthetic pathway. Chem Biol. 2000;7(6):395-403.

27. Duncan K, Haltli B, Gill KA, Kerr RG. Bioprospecting from marine sediments of New Brunswick, Canada: exploring the relationship between total bacterial diversity and actinobacteria diversity. Mar Drugs. 2014;12(2):899-925.

28. Ser H-L, Ab Mutalib N-S, Yin W-F, Chan K-G, Goh B-H, Lee L-H. Evaluation of Antioxidative and cytotoxic activities of Streptomyces pluripotens MUSC 137 isolated from mangrove soil in Malaysia. Front Microbiol. 2015;6:1398. 
29. Tan LTH, Ser HL, Yin WF, Chan KG, Lee LH, Goh BH. Investigation of Antioxidative and Anticancer Potentials of Streptomyces sp. MUM256 Isolated from Malaysia Mangrove Soil. Front Microbiol. 2015;6:1316.

30. Ser H-L, Yin W-F, Chan K-G, Khan TM, Goh B-H, Lee L-H. Antioxidant and cytotoxic potentials of Streptomyces gilvigriseus MUSC 26T isolated from mangrove soil in Malaysia. Prog Microbes Mol Biol. 2018;1(1).

31. Wong DZ, Kadir HA, Lee CL, Goh BH. Neuroprotective properties of Loranthus parasiticus aqueous fraction against oxidative stress-induced damage in NG108-15 cells. J Nat Med. 2012;66(3):544-51.

32. Tan LTH, Lee LH, Yin WF, Chan CK, Abdul Kadir H, Chan KG, Goh BH. Traditional Uses, Phytochemistry, and Bioactivities of Cananga odorata (Ylang-Ylang). Evid Based Complement Alternat Med. 2015;2015:896314.

33. Tan LTH, Low LE, Tang SY, Yap WH, Chuah LH, Chan CK, Lee LH, Goh $\mathrm{BH}$. A reliable and affortable $3 \mathrm{D}$ tumor spheroid model for natural product drug discovery: a case study of curcumin. Prog Drug Discov Biomed Sci. 2019;1(1)

34. Rao KVR, Rao TR. Molecular characterization and its antioxidant activity of a newly isolated Streptomyces coelicoflavus BC 01 from mangrove soil. J Young Pharm. 2013;5(4):121-6.

35. Miller ED, Kauffman CA, Jensen PR, Fenical W. Piperazimycins: cytotoxic hexadepsipeptides from a marine-derived bacterium of the genus Streptomyces. J Org Chem. 2007;72(2):323-30.

36. Mizui $Y$, Sakai T, Iwata M, Uenaka T, Okamoto $K$, Shimizu H, Yamori T, Yoshimatsu K, Asada M. Pladienolides, new substances from culture of Streptomyces platensis Mer-11107 III. In vitro and in vivo antitumor activities. J Antibiot. 2004;57(3):188-96.

37. Sack U, Walther W, Scudiero D, Selby M, Aumann J, Lemos C, Fichtner I, Schlag PM, Shoemaker RH, Stein U. S100A4-induced cell motility and metastasis is restricted by the Wnt/ $\beta$-catenin pathway inhibitor calcimycin in colon cancer cells. Mol Biol Cell. 2011;22(18):3344-54.

38. Conda-Sheridan M, Marler L, Park E-J, Kondratyuk TP, Jermihov K, Mesecar AD, Pezzuto JM, Asolkar RN, Fenical W, Cushman M. Potential chemopreventive agents based on the structure of the lead compound 2bromo-1-hydroxyphenazine, isolated from Streptomyces species, strain CNS284. J Med Chem. 2010;53(24):8688-99.

39. Kondratyuk TP, Park E-J, Yu R, Van Breemen RB, Asolkar RN, Murphy BT, Fenical W, Pezzuto JM. Novel marine phenazines as potential cancer chemopreventive and anti-inflammatory agents. Mar Drugs. 2012;10(2):451-64.

40. Whitman W, Parte A, Goodfellow M, Kämpfer P, Busse HJ, Trujillo M, Ludwig W, Suzuki K. Bergey's manual of systematic bacteriology: volume 5: the Actinobacteria. New York: Springer; 2012.

41. Mehta D, Satyanarayana T. Bacterial and archaeal a-amylases: diversity and amelioration of the desirable characteristics for industrial applications. Front Microbiol. 2016;7:1129.

42. Ser H-L, Law JW-F, Chaiyakunapruk N, Jacob SA, Palanisamy UD, Chan K-G, Goh B-H, Lee L-H. Fermentation conditions that affect clavulanic acid production in Streptomyces clavuligerus: a systematic review. Front Microbiol. 2016;7:522.

43. Zeng X, Chen XS, Ren XD, Wang L, Gao Y, Mao ZG. Improved $\varepsilon$-poly-l-lysine productivity partly resulting from rapid cell growth in cultures using a glucose-glycerol mixed carbon source. Eng Life Sci. 2016;16:443.

44. Srivibool R, Jaidee K, Sukchotiratana M, Tokuyama S, Pathom-aree W. Taxonomic characterization of Streptomyces strain CH54-4 isolated from mangrove sediment. Ann Microbiol. 2010;60(2):299-305.

45. Sengupta S, Pramanik A, Ghosh A, Bhattacharyya M. Antimicrobial activities of actinomycetes isolated from unexplored regions of Sundarbans mangrove ecosystem. BMC Microbiol. 2015;15(1):170.

46. Sanchez S, Chavez A, Forero A, García-Huante Y, Romero A, Sanchez M, Rocha D, Sánchez B, Ávalos M, Guzmán-Trampe S. Carbon source regulation of antibiotic production. J Antibiot. 2010;63(8):442-59.

47. Peskin AV, Winterbourn CC. A microtiter plate assay for superoxide dismutase using a water-soluble tetrazolium salt (WST-1). Clin Chim Acta. 2000;293(1):157-66.

48. Nishioka H, Imoto M, Sawa T, Hamada M, Naganawa H, Takeuchi T, Umezawa K. Screening of phosphatidylinositol kinase inhibitors from Streptomyces. J Antibiot. 1989:42(5):823-5.

49. Martins S, Mussatto SI, Martínez-Avila G, Montañez-Saenz J, Aguilar CN, Teixeira JA. Bioactive phenolic compounds: production and extraction by solid-state fermentation. A review. Biotechnol Adv. 2011;29(3):365-73.

50. Gopikrishnan V, Radhakrishnan M, Shanmugasundaram T, Pazhanimurugan R, Balagurunathan R. Antibiofouling potential of quercetin compound from marine-derived actinobacterium, Streptomyces fradiae PE7 and its characterization. Environ Sci Pollut Res. 2016;23(14):13832-42.

51. Ramos S. Cancer chemoprevention and chemotherapy: dietary polyphenols and signalling pathways. Mol Nutr Food Res. 2008:52(5):507-26.

52. Basri DF, ZAZ A, Chan KM. Assessment of cytotoxicity and genotoxicity of stem bark extracts from Canarium odontophyllum Miq.(dabai) against HCT 116 human colorectal cancer cell line. BMC Complement Altern Med. 2015;16(1):36.

53. Brito H, Martins AC, Lavrado J, Mendes E, Francisco AP, Santos SA, Ohnmacht SA, Kim N-S, Rodrigues CM, Moreira R. Targeting KRAS oncogene in colon cancer cells with 7-carboxylate indolo [3, 2-b] quinoline trialkylamine derivatives. PLoS One. 2015;10(5):e0126891.

54. Aisha AF, Abu-Salah KM, Ismail Z, Majid AMSA. In vitro and in vivo anticolon cancer effects of Garcinia mangostana xanthones extract. BMC Complement Altern Med. 2012;12(1):104.

55. Wyllie AH. Glucocorticoid-induced thymocyte apoptosis is associated with endogenous endonuclease activation. Nature. 1980;284(5756):555-6.

56. Henry CM, Hollville E, Martin SJ. Measuring apoptosis by microscopy and flow cytometry. Methods. 2013;61(2):90-7.

57. Riccardi $C$, Nicoletti I. Analysis of apoptosis by propidium iodide staining and flow cytometry. Nat Protoc. 2006;1(3):1458-61.

58. Darzynkiewicz Z, Bedner E. Analysis of apoptotic cells by flow and laser scanning cytometry. Methods Enzymol. 1999;322:18-39.

59. Goodfellow M. Phylum XXVI. Actinobacteria phyl. nov. In: Bergey's manual ${ }^{\circledR}$ of systematic bacteriology. New York: Springer; 2012. p. 33-2028.

60. Davelos AL, Xiao K, Flor JM, Kinkel LL. Genetic and phenotypic traits of streptomycetes used to characterize antibiotic activities of field-collected microbes. Can J Microbiol. 2004;50(2):79-89.

61. Barnes DK. High diversity of tropical intertidal zone sponges in temperature, salinity and current extremes. Afr J Ecol. 1999;37(4):424-34.

62. Gupta N, Mishra S, Basak U. Diversity of Streptomyces in mangrove ecosystem of Bhitarkanika. Iran J Microbiol. 2009;1(3):37-42.

63. Singh MP. Application of biolog FF MicroPlate for substrate utilization and metabolite profiling of closely related fungi. J Microbiol Methods. 2009; 77(1):102-8.

64. Birben E, Sahiner UM, Sackesen C, Erzurum S, Kalayci O. Oxidative stress and antioxidant defense. World Allergy Organ J. 2012;5(1):9.

65. Cruz de Carvalho MH. Drought stress and reactive oxygen species: production, scavenging and signaling. Plant Signal Behav. 2008;3(3):156-65.

66. Turrens JF. Mitochondrial formation of reactive oxygen species. J Physiol. 2003;552(2):335-44

67. Dahlgren C, Karlsson A. Respiratory burst in human neutrophils. J Immunol Methods. 1999;232(1):3-14.

68. Fransen M, Nordgren M, Wang B, Apanasets O. Role of peroxisomes in ROS/ RNS-metabolism: implications for human disease. Biochim Biophys Acta (BBA) - Mol Basis Dis. 2012;1822(9):1363-73.

69. Wang Y, Bao L, Liu D, Yang X, Li S, Gao H, Yao X, Wen H, Liu H. Two new sesquiterpenes and six norsesquiterpenes from the solid culture of the edible mushroom Flammulina velutipes. Tetrahedron. 2012;68(14): 3012-8.

70. Chan W-K, Tan LT-H, Chan K-G, Lee L-H, Goh B-H. Nerolidol: a sesquiterpene alcohol with multi-faceted pharmacological and biological activities. Molecules. 2016;21(5):529.

71. Kannabiran K. Characterization of antioxidant activity of Streptomyces species VITTK3 isolated from Puducherry Coast, India; 2010.

72. Brewer M. Natural antioxidants: sources, compounds, mechanisms of action, and potential applications. Compr Rev Food Sci Food Saf. 2011;10(4):221-47.

73. Huang D, Ou B, Prior RL. The chemistry behind antioxidant capacity assays. J Agric Food Chem. 2005;53(6):1841-56.

74. McKee KL. Interspecific variation in growth, biomass partitioning, and defensive characteristics of neotropical mangrove seedlings: response to light and nutrient availability. Am J Bot. 1995;82:299-307.

75. Ahmed D, Eide P, Eilertsen I, Danielsen S, Eknæs M, Hektoen M, Lind G, Lothe R. Epigenetic and genetic features of 24 colon cancer cell lines. Oncogenesis. 2013;2(9):e71.

76. Chen LB. Mitochondrial membrane potential in living cells. Annu Rev Cell Biol. 1988;4(1):155-81.

77. Zamzami N, Kroemer G. The mitochondrion in apoptosis: how Pandora's box opens. Nat Rev Mol Cell Biol. 2001;2(1):67-71.

78. Henry-Mowatt J, Dive C, Martinou J-C, James D. Role of mitochondrial membrane permeabilization in apoptosis and cancer. Oncogene. 2004:23(16): 2850-60. 
79. Schöller CE, Gürtler H, Pedersen R, Molin S, Wilkins K. Volatile metabolites from actinomycetes. J Agric Food Chem. 2002;50(9):2615-21.

80. Wang C, Wang Z, Qiao X, Li Z, Li F, Chen M, Wang Y, Huang Y, Cui H. Antifungal activity of volatile organic compounds from Streptomyces alboflavus TD-1. FEMS Microbiol Lett. 2013;341(1):45-51.

81. Citron CA, Barra L, Wink J, Dickschat JS. Volatiles from nineteen recently genome sequenced actinomycetes. Org Biomol Chem. 2015;13(9):2673-83.

82. Selvakumar JN, Chandrasekaran SD, Vaithilingam M. Bio prospecting of marine-derived Streptomyces spectabilis VITJS10 and exploring its cytotoxicity against human liver cancer cell lines. Pharmacogn Mag. 2015; 11(44):469.

83. Braun D, Pauli N, Séquin U, Zähner H. New butenolides from the photoconductivity screening of Streptomyces antibioticus (Waksman and woodruff) Waksman and Henrici 1948. FEMS Microbiol Lett. 1995; 126(1):37-42.

84. Sunesson A-L, Nilsson C-A, Carlson R, Blomquist G, Andersson B. Production of volatile metabolites from Streptomyces albidoflavus cultivated on gypsum board and tryptone glucose extract agar-influence of temperature, oxygen and carbon dioxide levels. Ann Occup Hyg. 1997;41(4):393-413.

85. Narayana KJ, Prabhakar P, Vijayalakshmi M, Venkateswarlu Y, Krishna PS Study on bioactive compounds from Streptomyces sp. ANU 6277. Pol J Microbiol. 2008;57(1):35.

86. Claeson A-S, Sandström M, Sunesson A-L. Volatile organic compounds (VOCs) emitted from materials collected from buildings affected by microorganisms. J Environ Monit. 2007;9(3):240-5.

87. Kumar PS, Duraipandiyan V, Ignacimuthu S. Isolation, screening and partial purification of antimicrobial antibiotics from soil Streptomyces sp. SCA 7. Kaohsiung J Med Sci. 2014;30(9):435-46.

88. Dickschat JS, Martens T, Brinkhoff T, Simon M, Schulz S. Volatiles released by a Streptomyces species isolated from the North Sea. Chem Biodivers. 2005; 2(7):837-65.

89. Elleuch L, Shaaban M, Smaoui S, Mellouli L, Karray-Rebai I, Fguira LF-B, Shaaban KA, Laatsch $\mathrm{H}$. Bioactive secondary metabolites from a new terrestrial Streptomyces sp. TN262. Appl Biochem Biotechnol. 2010; 162(2):579-93.

90. Jog R, Pandya M, Nareshkumar G, Rajkumar S. Mechanism of phosphate solubilization and antifungal activity of Streptomyces spp. isolated from wheat roots and rhizosphere and their application in improving plant growth. Microbiology. 2014;160(4):778-88.

91. Sulaiman SF, Yusoff NAM, Eldeen IM, Seow EM, Sajak AAB, Ooi KL. Correlation between total phenolic and mineral contents with antioxidant activity of eight Malaysian bananas (Musa sp.). J Food Compos Anal. 2011;24(1):1-10.

92. Yogeswari S, Ramalakshmi S, Neelavathy R, Muthumary J. Identification and comparative studies of different volatile fractions from Monochaetia kansensis by GCMS. Global J Pharm. 2012;6(2):65-71.

93. Narendhran S, Rajiv P, Vanathi P, Sivaraj R. Spectroscopic analysis of bioactive compounds from Streptomyces cavouresis kuv39: Evaluation of antioxidant and cytotoxicity activity. Int J Pharm Pharm Sci. 2014;6(7).

94. Prasad C. Bioactive cyclic dipeptides. Peptides. 1995;16(1):151-64.

95. Würth R, Barbieri F, Florio T. New molecules and old drugs as emerging approaches to selectively target human glioblastoma cancer stem cells. Biomed Res Int. 2014;2014:126586.

96. Vázquez-Rivera D, González O, Guzmán-Rodríguez J, Díaz-Pérez AL, OchoaZarzosa A, López-Bucio J, Meza-Carmen V, Campos-García J. Cytotoxicity of cyclodipeptides from Pseudomonas aeruginosa PAO1 leads to apoptosis in human cancer cell lines. Biomed Res Int. 2015;2015:197608.

97. Gopi M, Dhayanithi NB, Devi KN, Kumar TTA. Marine natural product, Pyrrolo [-a] pyrazine--dione, hexahydro-(C7H10N2O2) of antioxidant properties from Bacillus species at Lakshadweep archipelago. J Coast Life Med. 2014;2(8):632-7.

98. Lakshman SMV, Rao RC. Isolation and molecular characterization of anticancerous compound producing marine bacteria by using 165 rRNA sequencing and GC-MS techniques. Intern J Mod Eng Res. 2012;2:4510-5.

99. Hong S, Moon B-H, Yong Y, Shin SY, Lee YH, Lim Y. Inhibitory effect against Akt of cyclic dipeptides isolated from Bacillus sp. J Microbiol Biotechnol. 2008;18(4):682-5.

100. Takahashi Y, Matsumoto A, Seino A, Iwai Y, Omura S. Rare Actinomycetes Isolated from Desert Soils. 日本放線菌学会誌. 1996;10(2):91-7.

101. Shirling E, Gottlieb D. Method for characterization of Streptomyces species. Int J Syst Bacteriol. 1966;16:313 Citeseer.
102. Thompson JD, Gibson TJ, Plewniak F, Jeanmougin F, Higgins DG. The CLUSTAL_X windows interface: flexible strategies for multiple sequence alignment aided by quality analysis tools. Nucleic Acids Res. 1997;25(24): 4876-82.

103. Saitou N, Nei M. The neighbor-joining method: a new method for reconstructing phylogenetic trees. Mol Biol Evol. 1987;4(4):406-25.

104. Tamura K, Stecher G, Peterson D, Filipski A, Kumar S. MEGA6: molecular evolutionary genetics analysis version 6.0. Mol Biol Evol. 2013;30(12):2725-9.

105. Kimura M. A simple method for estimating evolutionary rates of base substitutions through comparative studies of nucleotide sequences. J Mol Evol. 1980;16(2):111-20.

106. Kim O-S, Cho Y-J, Lee K, Yoon S-H, Kim M, Na H, Park S-C, Jeon YS, Lee J-H, Yi $\mathrm{H}$. Introducing EzTaxon-e: a prokaryotic $16 \mathrm{~S}$ rRNA gene sequence database with phylotypes that represent uncultured species. Int J Syst Evol Microbiol. 2012;62(Pt 3):716-21.

107. Felsenstein J. Confidence limits on phylogenies: an approach using the bootstrap. Evolution. 1985:783-91.

108. Atlas RM. Handbook of microbiological media. Boca Raton: CRC press; 2010.

109. Küster $E$, Williams S. Media for the isolation of streptomycetes: starch casein medium. Nature. 1964:202:928-9.

110. Mac Faddin JF. Biochemical tests for identification of medical bacteria. Baltimore: Williams \& Wilkins Co; 1976.

111. Kelly KL. ISCC-NBC color-name charts illustrated with centroid colors; 1964.

112. Cerny G. Studies on the aminopeptidase test for the distinction of gramnegative from gram-positive bacteria. Eur J Appl Microbiol Biotechnol. 1978; 5(2):113-22.

113. Lee L-H, Zainal N, Azman A-S, Ab Mutalib N-S, Hong K, Chan K-G. Mumia flava gen. nov., sp. nov., an actinobacterium of the family Nocardioidaceae. Int J Syst Evol Microbiol. 2014;64(Pt 5):1461-7.

114. Carrillo P, Mardaraz C, Pitta-Alvarez S, Giulietti A. Isolation and selection of biosurfactant-producing bacteria. World J Microbiol Biotechnol. 1996; 12(1):82-4.

115. Meena B, Rajan LA, Vinithkumar NV, Kirubagaran R. Novel marine actinobacteria from emerald Andaman \& Nicobar Islands: a prospective source for industrial and pharmaceutical byproducts. BMC Microbiol. 2013; 13(1):145.

116. Shieh WY, Chen Y-W, Chaw S-M, Chiu H-H. Vibrio ruber sp. nov., a red, facultatively anaerobic, marine bacterium isolated from sea water. Int J Syst Evol Microbiol. 2003:53(2):479-84

117. Tan LT-H, Chan K-G, Chan CK, Khan TM, Lee L-H, Goh B-H. Antioxidative Potential of a Streptomyces sp. MUM292 Isolated from Mangrove Soil. Biomed Res Int. 2018:2018:13.

118. Tan LT-H, Chan K-G, Khan TM, Bukhari SI, Saokaew S, Duangjai A, Pusparajah P, Lee L-H, Goh B-H. Streptomyces sp. MUM212 as a source of antioxidants with radical scavenging and metal chelating properties. Front Pharmacol. 2017:8:276.

119. Zhang Q, Zhang J, Shen J, Silva A, Dennis DA, Barrow CJ. A simple 96-well microplate method for estimation of total polyphenol content in seaweeds. J Appl Phycol. 2006;18(3):445-50.

120. Herald TJ, Gadgil P, Tilley M. High-throughput micro plate assays for screening flavonoid content and DPPH-scavenging activity in sorghum bran and flour. J Sci Food Agric. 2012;92(11):2326-31.

121. Goh BH, Kadir A. In vitro cytotoxic potential of Swietenia macrophylla King seeds against human carcinoma cell lines. J Med Plant Res. 2011 5(8):1395-404.

122. Supriady H, Kamarudin MNA, Chan CK, Goh BH, Kadir HA. SMEAF attenuates the production of pro-inflammatory mediators through the inactivation of Akt-dependent NF-KB, p38 and ERK1/2 pathways in LPS-stimulated BV-2 microglial cells. J Funct Foods. 2015;17:434-48.

123. Silici S, Sagdic O, Ekici L. Total phenolic content, antiradical, antioxidant and antimicrobial activities of Rhododendron honeys. Food Chem. 2010; 121(1):238-43. 